\title{
US Interest Rate Policy Spillover and International Capital Flow: Evidence from Korea
}

\author{
Jieun Lee*, Jung-Min Kim*, Jong Kook Shin ${ }^{* * *}$
}

The views expressed herein are those of the authors and do not necessarily reflect the official views of the Bank of Korea. When reporting or citing this paper the authors' names should always be explicitly stated.

\footnotetext{
* Economist, Economic Research Institute, The Bank of Korea, Tel: +82-2-759-5740, Email:jelee@bok.or.kr.

** Assistant Professor of Finance, University of Seoul, Tel: +82-2-6490-2259, Email: kimjm2016@uos.ac.kr. *** Corresponding Author, Professor, Newcastle University Business School, E-mail: jong.shin@newcastle.ac.uk.

The authors thank the comments from the Economic Research Institute (ERI) of the Bank of Korea, which help improve this study significantly. The authors also acknowledge financial support from the Bank of Korea. All errors are our own.
} 


\section{Contents}

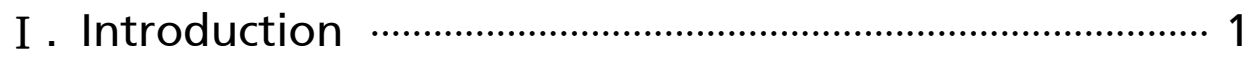

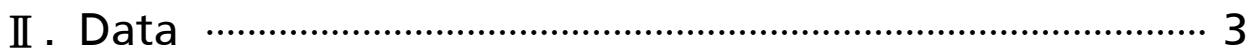

III. US Monetary Policy ………………………………………... 12

IV. Empirical Results …………………..................................... 15

V. Concluding Remarks …………………………………...... 29

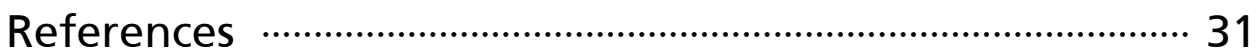

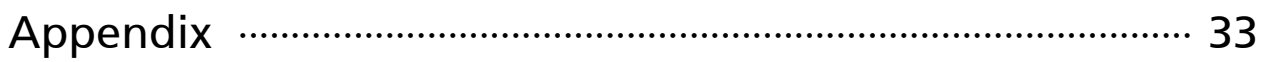




\section{US Interest Rate Policy Spillover and International Capital Flow: Evidence from Korea}

Using the novel high frequency capital flow dataset from the EPFR Global, this study empirically investigates the spillover effects of the US Fed's monetary policy on the international capital flow in South Korea. Around the Fed's monetary policy announcement (event) week, we find that equity investors appear to temporarily increase (decrease) their portfolio holdings in South Korea upon a more-than-expected contractionary (expansionary) interest rate policy, while bond investors do not change their portfolio holdings much. This result is robust to the exclusion of influential observations, alternative estimation methods as well as inclusion of an additional explanatory variable which explicitly controls for possible endogeneity. Additionally, we conduct the full sample regression analysis including event and non-event weeks after controlling for the pull and push factors that are likely to be associated with the international capital flow. Our empirical evidence shows that unexpected US policy shocks have a significant negative impact on certain types of international capital flow. Specifically, the unexpected US contractionary monetary policy appears to be associated with equity fund outflow from the US, passive and institutional investors and bond fund outflow from retail investors.

Keywords: US monetary policy, Interest rate policy, Spillover, Capital flow, High frequency identification, Event study

JEL Classification: E44, E52, E58, F32 


\section{I . Introduction}

It is widely accepted that the federal fund target rate (FFTR) has been one of the most important policy vehicles available to the US Federal Reserve since the former chairman Paul Volcker. Many studies have shown that the Fed's interest rate policy directly affects asset prices such as interest rates, bond yields and broad-based equity indices in the US and other countries (e.g. Kuttner 2001, Bernanke and Kuttner 2005, Craine and Martin 2008). More recently, Cieslak, Morse and Vissing-Jorgensen (2014) document that the cycle of the Federal Open Market Committee (FOMC) meeting, in which the FFTR is determined, explains the entire risk premium of the US and the world equity markets since 1994. However, much less is known about the effect of the Fed's monetary policy on the behavior of the international capital flow at the high frequency level. This is the gap we aim to fill in our study.

We empirically investigate the causal relationship between the US monetary policy and international capital flow using novel high frequency data obtained through the EPFR Global. We focus on the capital flow in one emerging market, namely South Korea. Such a choice is motivated by empirical aspects of the problem. In order to identify the causal relationship with a minimal set of assumptions, we want to retain homogeneity within our sample. Although a well-designed cross-country study can benefit from improved efficiency, it may fail to illuminate important country specific patterns. A handful of influential countries may drive the entire results too. A multi-country exercise has risk of unnecessarily complicating the picture and distracting attention from the main issue. South Korea is selected largely because of its presence and importance in the emerging markets. The country has one of the largest stock markets in terms of market capitalization and trading value among the emerging markets. The size of its bond market relative to GDP is comparable to many of its peer. The economy's link with the US has been reasonably high and stable too.

Our study starts by estimating the total effect of the Fed's policy interest rate shift on the international fund flows in South Korean markets. Then the total 
effect is decomposed into the anticipated and unanticipated components. This type of studies can become easily complicated because of the identification issue. As suggested by Taylor (1993), it is widely accepted that the Fed responds to certain macroeconomic variables for its interest rate policy. In conventional studies based on low frequency data, it is difficult to tell which part of the Fed's policy change corresponds to the policy surprise without invoking non-trivial assumptions. With the new high frequency capital flow dataset from the EPFR Global, we can cleanly isolate the policy shock by applying the event-study type identification strategy (Kuttner, 2001, Cochrane and Piazzesi 2003). This dataset also allows us to examine the behaviors of the capital flow at the disaggregated levels such as the asset type, management style, type of investors, country of fund source, etc.

Our study finds pretty rich and novel results concerning the international capital flow around the Fed's policy event weeks. We show that international investors tend to increase their equity position in South Korea during the week in which the Fed has increased its policy interest rate target. Further, a positive policy surprise to the Fed's interest rate policy is associated with a large equity capital inflow too. While some international investors respond to the expected component of US monetary policy, this tends to be smaller than the effect of the shock. This finding is robust to exclusion of influential observations and alternative estimation strategies. We also try to control for a source of endogeneity by directly including the variable. The result is still robust. Most striking is that a model of asymmetric response over the US business cycle can explain majority of variation in international equity flow in S. Korea. It can explain the variation in a certain type of equity flows as high as $70 \%$. For the equity flows, the effect of the Fed's policy is found minimal outside the policy week. More specifically, the weekly equity flow responds only to the contemporaneous policy shock.

The effect of the Fed's policy on the bond flow is found mixed when we focus on the event-week sample only. i.e. the signs on the policy (shock) are different across the regressions with different types of bond funds. However, this does not 
seem robust. A battery of exercises suggests that some groups of international bond traders in South Korea have made a pre-emptive portfolio rebalancing in anticipation of the policy shock. When this effect is taken into account, the sign on the policy surprise is positive for all statistically significant estimators. On balance, our study indicates that a contractionary US policy shock leads to inflow of international portfolio investment in South Korea. This result is at odds with the literature adopting different methodologies. We show that our finding is not due to the identification method itself, nor due to the high frequency data. Rather, it is possible that the shocks measured in the existing studies might be capturing information different from the true policy shock.

Building on the literature, we additionally conduct the full-sample regression analysis including event and non-event weeks. For the analysis, we also control for the push and pull factors that are likely to be associated with the international capital flow. In this exercise, consistent with the previous literature, we find that unexpected US policy shocks have a significant negative impact on certain types of international capital flow in South Korea. Specifically, the Fed's positive interest rate shocks appear to be associated with equity fund outflow from passive, US, and institutional investors and bond fund outflow from retail investors.

Section I describes our high frequency data and offer a comparison with a lower frequency dataset from the country's balance of payment. Section II explains the US monetary policy event and the methodology to construct the high frequency shock measure. Section III presents the main empirical findings and a battery of robust tests, along with some discussion on the identifying assumptions. Section IV discusses the results. Section V concludes.

\section{Data}

Our main data are collected from several distinct sources: We download monthly and weekly international capital flow from the EPFR Global. The 
monthly balance of payment is obtained from the Bank of Korea website. The dates of historical FOMC meetings and conference calls are hand collected from the Federal Reserve webpage. We use the Datastream for the federal fund rate futures prices. All other data are gathered through the Haver Analytic platform.

While the EPFR Global database entails only a subset of the total international capital flow, it has been understood that its coverage is representative of the aggregate flow in the cross-country settings (see Jotikasthira et al., 2012 and Fratzscher, 2012). However, what is less known is the degree to which the EPFR data cover the fund flow by asset type within a country and how do they compare with the numbers from the national sources. Therefore, this new dataset deserves some descriptive exploration. For this exercise, we are bound to use monthly data as the balance of payment (BOP) is unavailable at a higher frequency. We take the $\mathrm{BOP}$ as the true population.

Table 1 presents the summary. Panel A shows that the EPFR data have about $39 \%$ of mean and $31 \%$ of standard deviation relative to the BOP account, when the aggregate capital flow (equity + bond) is concerned. A careful look the statistics reveals an interesting point. The average equity portfolio flow reported by the EPFR Global is about 3.7 times greater than the number obtained from the national account. Considering that the EPFR Global is a subsample of the BOP, this may appear bizarre at first glance. A closer look at two datasets, however, suggests that the EPFR seems indeed a proper subset of the population (BOP). Figure 1 visually compares the distributions of the monthly capital flows from these two sources. Panel A compares the aggregate capital flow. Panels B and C show the distributions of equity and bond flow. The distributions from the BOP and EPFR have similar midpoints, while the EPFR sample has a much smaller dispersion. Panel C of Table 1 formalizes this point by comparing the sample means of two samples. The difference in mean of aggregate flow from two datasets is significant only at $10 \%$. 
Table 1: Monthly Aggregate Net Capital Flow from EPFR and Balance of Payment (BOP)

Panel A: Comparison of key statistics (Unit: \$, million)

\begin{tabular}{llrrrr}
\multicolumn{1}{c}{ Variable } & \multicolumn{1}{c}{ Source } & \multicolumn{1}{c}{ Mean } & \multicolumn{1}{c}{ Std Dev } & \multicolumn{1}{c}{ Min } & \multicolumn{1}{c}{ Max } \\
\hline \multirow{5}{*}{ Total } & BOP & 840.76 & 3239.00 & -7606.00 & 8482.00 \\
& EPFR & 331.64 & 1002.00 & -2355.00 & 3621.00 \\
Equity & \% Ratio & 39.45 & 30.94 & 30.96 & 42.69 \\
& BOP & 72.90 & 2959.00 & -10499.00 & 8429.00 \\
& EPFR & 270.01 & 919.17 & -2242.00 & 3054.00 \\
& \% Ratio & 370.39 & 31.06 & 21.35 & 36.23 \\
Debt (bond) & BOP Debt & 767.86 & 1948.00 & -5193.00 & 9656.00 \\
& EPFR Bond & 61.63 & 180.72 & -734.44 & 567.33 \\
& \% Ratio & 8.03 & 9.28 & 14.14 & 5.88 \\
\hline
\end{tabular}

Panel B: Spearman rank correlation

\begin{tabular}{|c|c|c|c|c|c|c|c|c|}
\hline & $\begin{array}{l}\text { Total } \\
\text { BOP }\end{array}$ & $\begin{array}{c}\text { Total } \\
\text { EPFR }\end{array}$ & $\begin{array}{l}\text { BOP } \\
\text { Equity }\end{array}$ & $\begin{array}{l}\text { EPFR } \\
\text { Equity }\end{array}$ & $\begin{array}{l}\text { BOP } \\
\text { Debt }\end{array}$ & $\begin{array}{c}\text { BOP LT } \\
\text { Debt }\end{array}$ & $\begin{array}{c}\text { BOP ST } \\
\text { Debt }\end{array}$ & $\begin{array}{l}\text { EPFR } \\
\text { Bond }\end{array}$ \\
\hline Total BOP & 1.00 & $0.59^{* *}$ & $0.84^{* *}$ & $0.55^{* *}$ & $0.49^{* *}$ & $0.40^{* *}$ & $0.25^{* *}$ & $0.44^{* *}$ \\
\hline Total EPFR & $0.59^{* *}$ & 1.00 & $0.55^{* *}$ & $0.98^{* *}$ & $0.26^{* *}$ & $0.19^{*}$ & $0.15 \dagger$ & $0.49^{* *}$ \\
\hline BOP Equity & $0.84^{* *}$ & $0.55^{* *}$ & 1.00 & $0.53^{* *}$ & 0.07 & 0.02 & -0.01 & $0.38^{* *}$ \\
\hline EPFR Equity & $0.55^{* *}$ & $0.98^{* *}$ & $0.53^{* *}$ & 1.00 & $0.21^{* *}$ & $0.14 \dagger$ & 0.11 & $0.36^{* *}$ \\
\hline $\begin{array}{l}\text { BOP } \\
\text { Debt }\end{array}$ & $0.49^{* *}$ & $0.26^{* *}$ & 0.07 & $0.21^{* *}$ & 1.00 & $0.88^{* *}$ & $0.49^{* *}$ & $0.34^{* *}$ \\
\hline BOP LT Debt & $0.40^{* *}$ & $0.19^{* *}$ & 0.02 & $0.14 \dagger$ & $0.88^{* *}$ & 1.00 & $0.14 \dagger$ & $0.32^{* *}$ \\
\hline BOP ST Debt & $0.25^{* *}$ & $0.15^{*}$ & -0.01 & 0.11 & $0.49^{* *}$ & $0.14 \dagger$ & 1.00 & $0.17^{*}$ \\
\hline EPFR Bond & $0.44^{* *}$ & $0.49^{* *}$ & $0.38^{* *}$ & $0.36^{* *}$ & $0.34^{* *}$ & $0.32^{* *}$ & $0.17^{*}$ & 1.00 \\
\hline
\end{tabular}

Panel C: Difference in mean

\begin{tabular}{lrrrr} 
& BOP $(\mathrm{A})$ & EPFR $(\mathrm{B})$ & Diff $(\mathrm{A}-\mathrm{B})$ & \multicolumn{1}{c}{ p-value } \\
Aggregate & 840.8 & 331.6 & 509.1 & 0.0796 \\
Equity & 72.9 & 270.0 & -197.1 & 0.456 \\
Debt/Bond & 767.9 & 61.6 & 706.2 & $\langle .0001$ \\
\hline
\end{tabular}

Notes: 1) The number of sample is 138, over January $2004 \sim$ June 2015.

2) $\%$ Ratio in Panel $A$ is computed by (EPFR/BOP)* 100 .

3) BOP LT Debt and BOP ST Debt are BOP Long-Term Debt and BOP Short-term Debt, respectively.

4) $\dagger, *$, and $* *$ denote statistical significance at $10 \%, 5 \%$ and $1 \%$ respectively. 
Figure 1: Histograms of Monthly Capital Flow from EPFR and BOP (Unit: \$, million)

Panel A: Aggregate capital flow

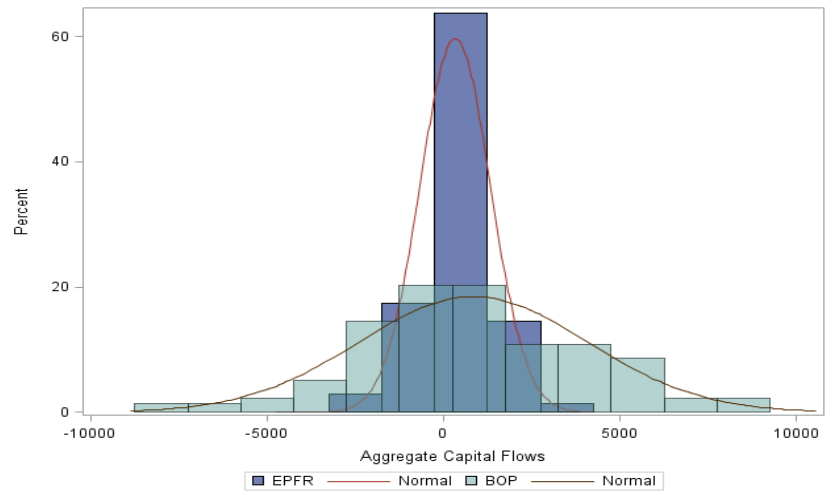

Panel B: Equity flow Panel C: Bond or debt flow
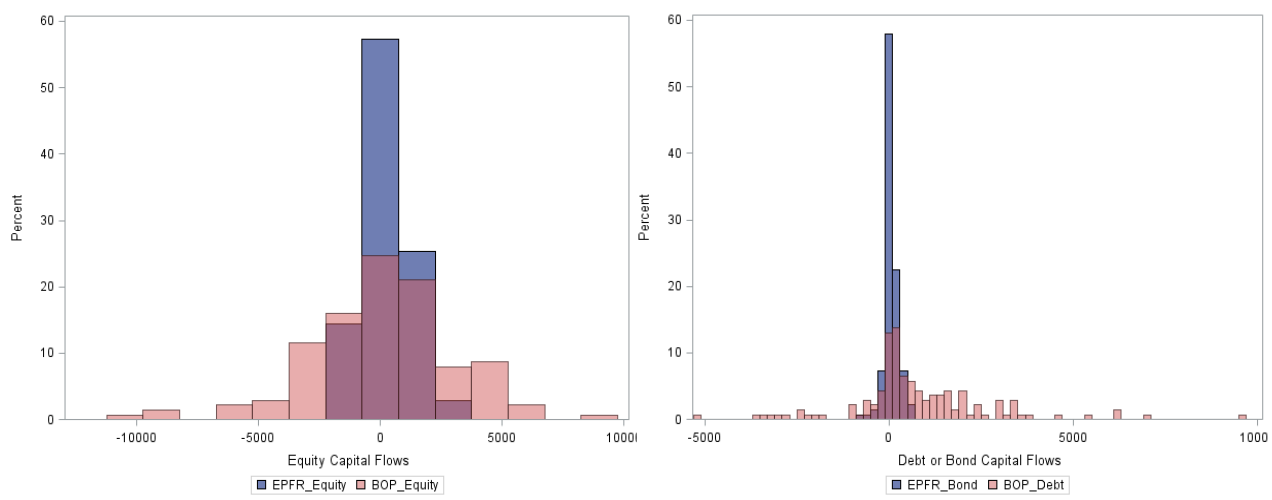

Moreover, one cannot reject equality of means of the equity flow for any conventional significance level $(p=0.456)$. However, the means of the bond flow appear different $(p<0.001)$.

What is more important for our study is the correlation of the comparable type of capital flows from two sources. When we are assured a reasonable positive co-movement between them, we can use the EPFR data as a higher frequency proxy for the true capital flow. Panel B of Tablel reports the Spearman correlation. Indeed, the correlation is high and significant. The aggregate capital flow from the BOP and EPFR has the Spearman rank correlation 
Table 2: Weekly EPFR Capital Flow by Fund Type (Unit: \$, million)

\begin{tabular}{llrrrr}
\multicolumn{1}{c}{ Variable } & & Mean & Std Dev & Min & Max \\
Aggregate & Total & 53.34 & 271.29 & -1045.67 & 1193.11 \\
& Equity & 44.45 & 260.45 & -1032.66 & 1129.12 \\
\multirow{5}{*}{ Active Fund } & Bond & 8.89 & 32.92 & -180.25 & 112.40 \\
& Total & 15.50 & 124.72 & -558.88 & 414.63 \\
& Equity & 7.72 & 115.56 & -562.12 & 404.33 \\
\multirow{5}{*}{ Passive Fund } & Bond & 7.78 & 22.62 & -139.52 & 116.21 \\
& Total & 38.43 & 132.22 & -630.87 & 602.27 \\
& Equity & 37.14 & 131.52 & -624.88 & 595.09 \\
Institutional & Bond* & 1.78 & 5.58 & -48.99 & 36.00 \\
& Total & 49.55 & 164.76 & -686.21 & 791.45 \\
& Equity & 45.26 & 160.63 & -686.66 & 756.20 \\
Retail & Bond & 4.29 & 12.08 & -67.75 & 120.91 \\
& Total & 7.15 & 83.22 & -475.48 & 682.17 \\
& Equity & 2.29 & 84.61 & -480.85 & 627.07 \\
& Bond & 4.86 & 16.07 & -73.38 & 63.89 \\
\hline
\end{tabular}

Notes: 1) The number of observation is 603 except for passive bond where it is only 436 . This is because data on passive bond flow are available starting from 12w2007.

2) Weekly EPFR sample is over 1w2004 to 29w2015.

coefficient $^{1)}$ of 0.59 . The correlation of monthly equity flow is 0.53 . The correlation of bond and total debt flow is 0.34. Moreover, it appears that EPFR bond flow track the long-term debt flow more closely than the short-term debt flow (0.32 vs. 0.17$)$. Most of these are statistically significant at the $1 \%$ level.

The strength of the EPFR dataset is that it allows us to decompose the aggregate capital flow by various criteria. We first report the EPFR weekly fund flow by the management style and investor in Table 2. It shows that, in the EPFR sample, the equity flow is much greater than the bond flow across all fund types. Moreover, the equity flow is mostly passive and institutional. And a majority of international bond investment is made through active funds in South Korea. The bond flow is much more stable (smaller variance) than the equity flow across all types of funds.

1) Given the difference in magnitude, we believe that the Spearman rank correlation is more appropriate. In unreported exercises, we have also performed comparison using the Pearson correlation. We find similar qualitative results. 
Then we examine the EPFR weekly sample by the country of fund source. This exercise is restricted to the series with a sufficiently large sample size. In particular, we only consider series where the number of sample is greater 300 . While this is an arbitrary cutoff, this corresponds roughly to a half of the total sample size. Also, the included countries account for $69 \%$ of variance in the aggregate EPFR equity flow and $74 \%$ of variance in the aggregate EPFR bond flow, respectively. Table 3 reports the summary statistics for equity and bond flows. The table is reported in a descending order with respect to the sample standard deviation. While the conventional financial hub countries such as the US and the UK rank high in the list, tax heavens such as Luxembourg, Ireland, Switzerland, Guernsey, Cayman Islands, etc also represent a sizeable portion of the variation in the international capital flow in South Korea. Figure 2 illustrates the time series behavior of the equity and the bond flows for top 3 countries $^{2}$ ) and the rest of world (RoW). The RoW is calculated by taking out the top three countries from the total flow. It turns out that the US, Luxembourg and Ireland are most influential foreign countries in both equity and bond markets of South Korea. A visual examination indicates that the trading of different types of funds does not always move in tandem. This observation suggests that a micro-fund type level study would be beneficial.

For the equity flow, the contribution of the top country (US) is larger than the RoW for the most periods. For the bond flow, the reverse is true. The bond flow from the rest of world seems to account for a greater part of the total flow than the top three combined. Even within the top 3, the contribution of the smallest country seems modest at best, for both equity and bond markets.

2) Flow being signed variable, ranking by the first moment can be misleading. Instead we rank countries with respect to the full sample variance. While Netherlands shows slightly larger variance than Ireland in the bond flow, we prefer Ireland for one of our top 3 countries as the former does not cover the full sample period. However, this does not alter the results much. 


\section{$9 \quad$ BOK Working Paper No. 2016-21}

Table 3: Weekly EPFR Net Capital Flow by Country of Fund Source (Unit: \$, million)

Panel A: Equity flow by source country

\begin{tabular}{lcrrrr}
\multicolumn{1}{c}{ Country } & N & Mean & Std Dev & \multicolumn{1}{c}{ Min } & Max \\
USA & 603 & 34.45 & 146.09 & -559.11 & 717.77 \\
Luxembourg & 603 & 5.79 & 76.99 & -366.82 & 581.43 \\
Ireland & 603 & 3.75 & 38.77 & -439.83 & 237.96 \\
UK & 603 & -0.23 & 14.88 & -76.71 & 55.68 \\
France & 603 & -1.14 & 12.46 & -78.51 & 48.30 \\
Switzerland & 603 & -0.18 & 5.73 & -91.52 & 38.30 \\
Belgium & 589 & -0.10 & 3.98 & -29.18 & 38.08 \\
Germany & 593 & -0.79 & 3.91 & -24.11 & 17.60 \\
Guernsey & 603 & -0.57 & 3.63 & -27.93 & 21.59 \\
Australia & 329 & 0.20 & 3.32 & -31.86 & 36.08 \\
Cayman Islands & 603 & 0.74 & 3.13 & -20.02 & 24.84 \\
Jersey & 389 & -0.15 & 3.05 & -59.75 & 4.11 \\
Canada & 603 & -0.08 & 2.97 & -23.44 & 34.24 \\
Hong Kong & 314 & -0.34 & 2.70 & -21.04 & 19.71 \\
Denmark & 509 & -0.15 & 2.53 & -53.27 & 4.40 \\
Netherlands & 463 & -0.14 & 2.38 & -17.20 & 19.27 \\
Austria & 603 & -0.03 & 1.40 & -10.54 & 13.77 \\
Singapore & 313 & -0.15 & 0.80 & -7.93 & 1.58 \\
Estonia & 300 & -0.01 & 0.21 & -2.15 & 1.61 \\
\hline
\end{tabular}

Panel B: Bond flow by source country

\begin{tabular}{lcrrrr}
\multicolumn{1}{c}{ Country } & $N$ & Mean & Std Dev & Minimum & Maximum \\
Luxembourg & 603 & 4.98 & 19.24 & -135.04 & 117.73 \\
USA & 603 & 3.12 & 7.55 & -48.25 & 42.89 \\
Netherlands & 436 & 0.57 & 4.10 & -49.06 & 35.93 \\
Ireland & 603 & 0.73 & 3.13 & -24.16 & 10.44 \\
Guernsey & 492 & -0.01 & 2.03 & -20.03 & 14.14 \\
UK & 513 & 0.48 & 1.82 & -9.83 & 7.12 \\
Switzerland & 513 & 0.01 & 1.35 & -7.41 & 12.88 \\
Canada & 513 & 0.31 & 0.79 & -2.90 & 5.46 \\
France & 311 & -0.04 & 0.69 & -5.20 & 2.77 \\
Germany & 311 & -0.04 & 0.69 & -5.20 & 2.77 \\
Cayman Islands & 406 & -0.02 & 0.31 & -3.71 & 2.08 \\
Austria & 513 & 0.00 & 0.27 & -1.44 & 2.99 \\
Denmark & 509 & -0.02 & 0.10 & -0.90 & 1.09 \\
Greece & 332 & 0.00 & 0.01 & -0.11 & 0.13 \\
\hline
\end{tabular}

Notes: All series with $N \geq 300$ are included for report. They account for $69 \%$ of variance in the aggregate EPFR equity flow and $74 \%$ of variance in the aggregate EPFR bond flow, respectively. 
Figure 2: Time Series Plots of Weekly EPFR Capital Flow (Unit: \$, million)

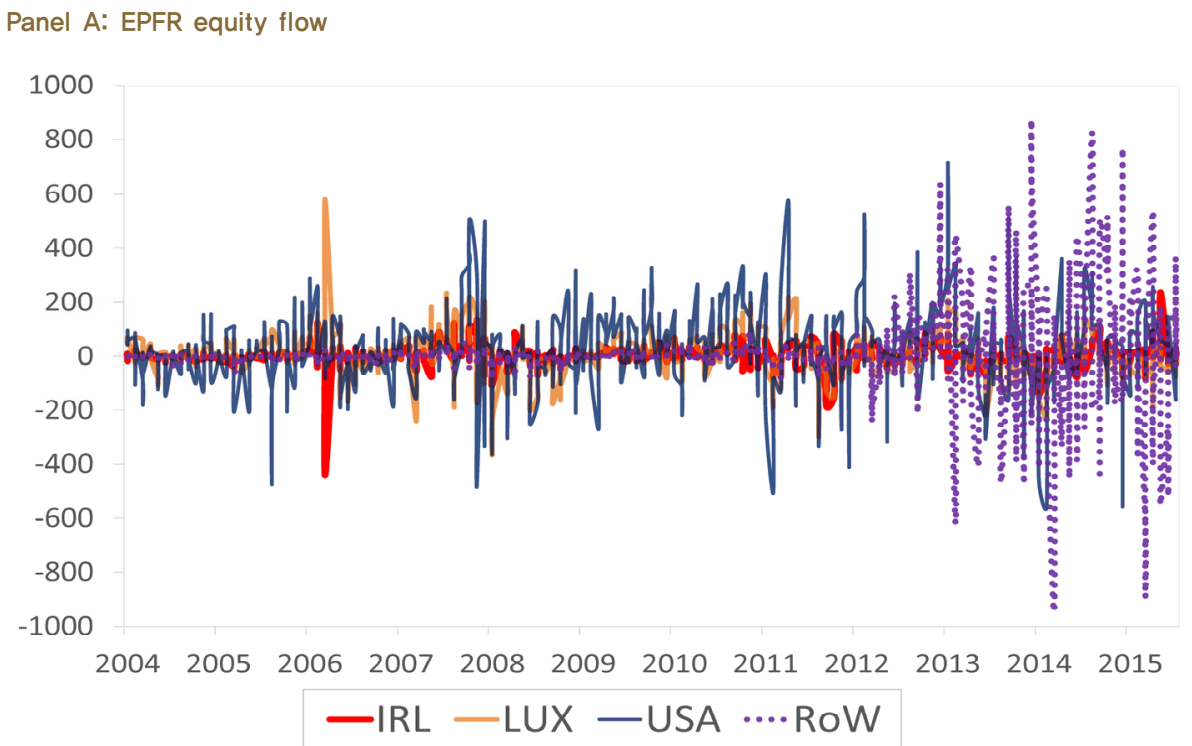

Panel B: EPFR bond flow

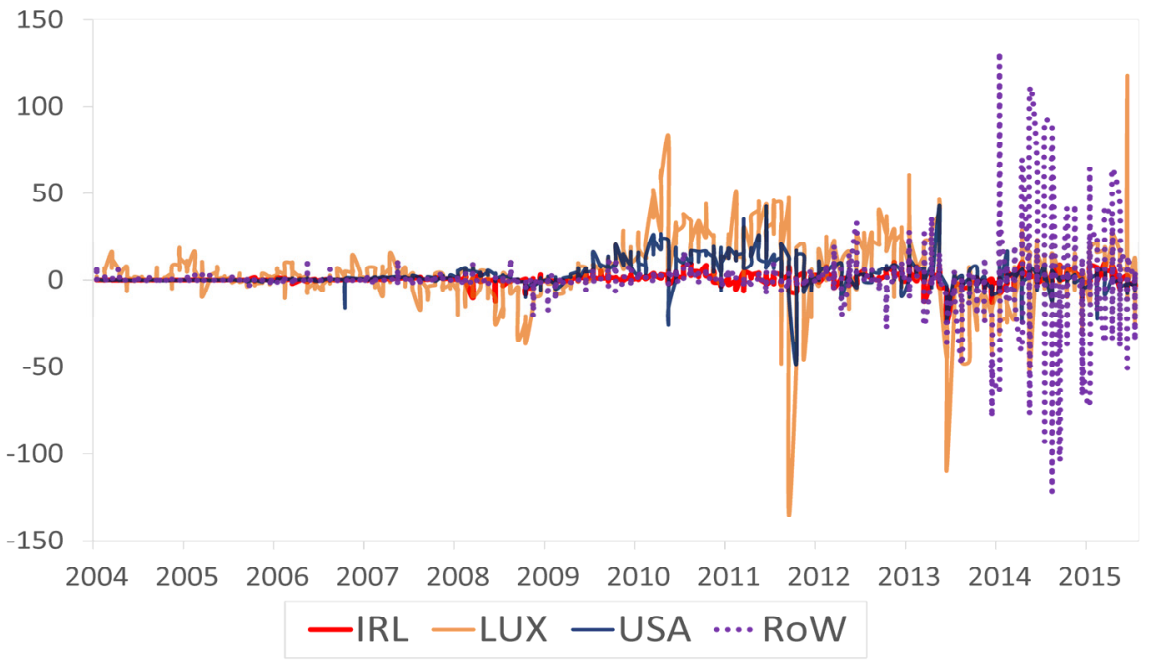

Notes: The three letters in legend indicate the country ISO codes. USA, LUX and, IRL represent the US, Luxembourg, and Ireland, respectively. RoW denotes the rest of world and is computed by the total flow minus the top three countries. 
Figure 3: Time Series Plots of Weekly EPFR Holdings (Unit: \$, million)

Panel A: EPFR equity holdings

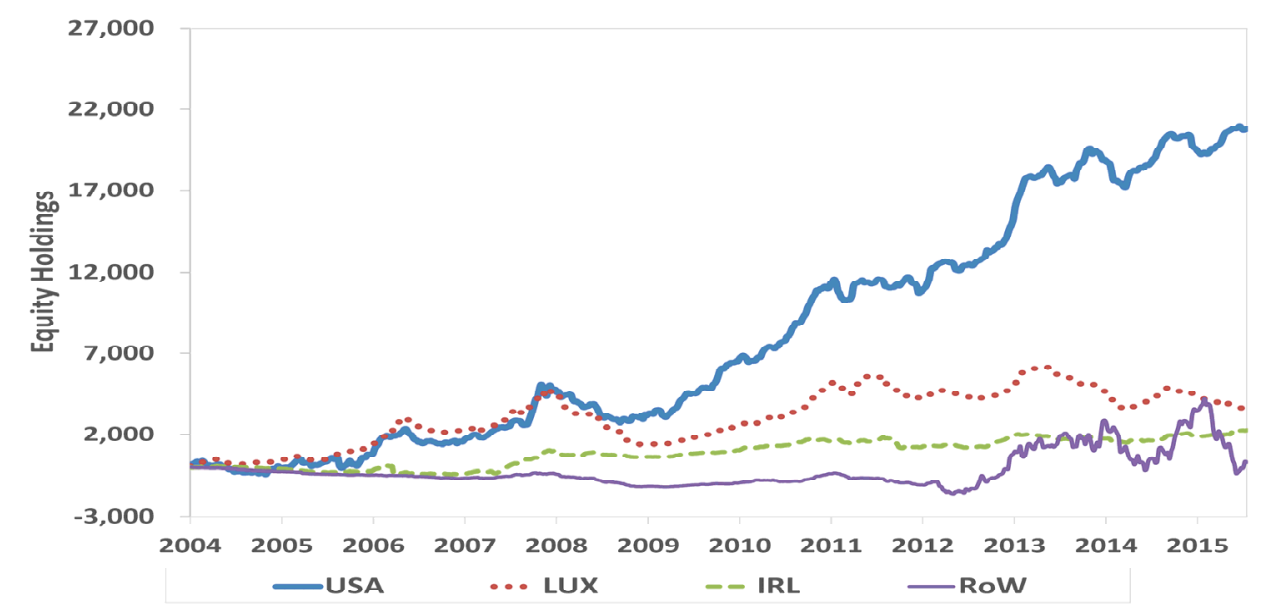

Panel B: EPFR bond holdings

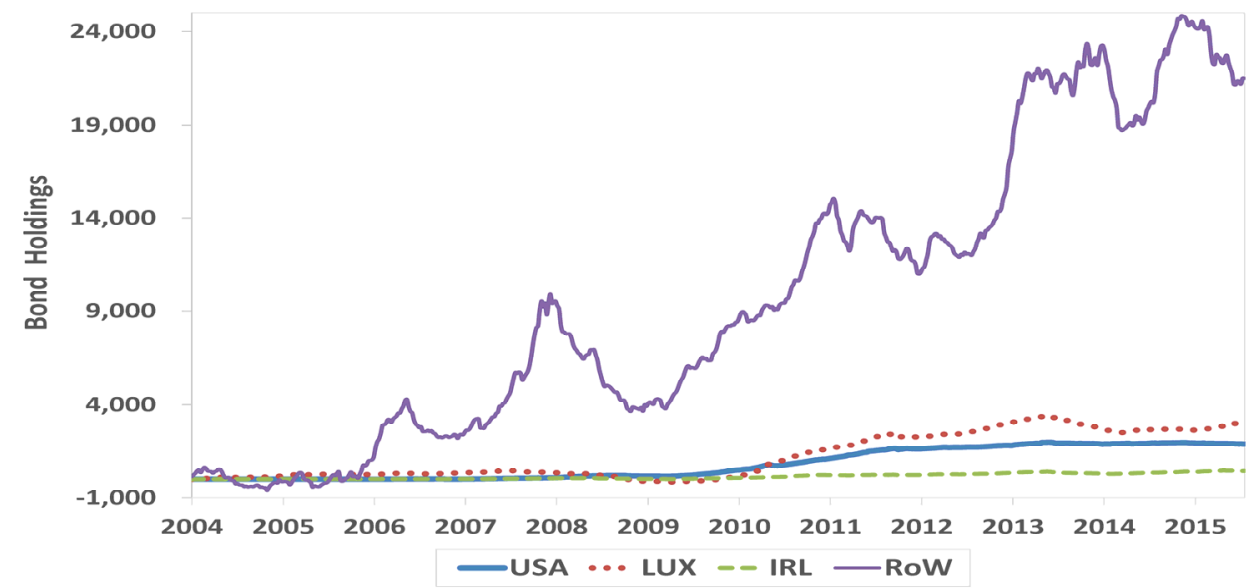

Notes: The three letters in legend indicate the country ISO codes. USA, LUX and IRL represent the US, Luxembourg, and Ireland, respectively. RoW denotes the rest of world and is computed by the total flow minus the top three countries. The holdings are inferred from the cumulative sum of the flow by setting the initial holdings to zero.

Figure 3 illustrates the equity and the bond holdings. The holding is inferred from the cumulative sum of the flow. This treatment will give the correct picture concerning the trend in holdings, but not necessarily about the 
levels due to the unknown initial level. The US equity has increased steadily and most rapidly. By the middle of the sample period, the US equity holdings account for more of the foreign equity holdings in $\mathrm{S}$ Korea than all others combined. Its importance has increased even further as time passes. On the other hand, the bond holdings by top three countries are overshadowed by the RoW.

\section{US Monetary Policy}

\section{US Monetary policy events}

The entire sample period for our analysis expands over a total of 603 weeks between the first week of 2004 and the $29^{\text {th }}$ week of 2015 . While other series are available over an extended period, the EPFR high frequency capital flow is available only from week 1 of 2004 for S Korea. During the sample period, there are a total of 108 weeks in which FOMC meetings or Fed conference calls are held. 18 of them were unscheduled meetings or conference calls while the rest are scheduled. Out of total 108 meetings, the Fed has released a brief statement immediately after 96 meetings ${ }^{3)}$. The Fed has made no immediate announcements after 12 meetings, all of which are unscheduled. Discussions in these meetings continue/expand in the follow-up meetings typically held within one or two weeks.

The contents of typical statements include the Fed's outlook about the economy, the policy stance and the federal fund target rate (FFTR). Often, the FFTR is considered a good summary statistics of the Fed's statements. For instance, a decrease in FFTR is considered a (preventive) measure to fight economic slowdown. Often it is understood that a larger change in FFTR indicates a stronger desire/need to stabilize the business cycle fluctuations. Naturally, the FFTR increases/decreases cluster around the business cycle. In

3) When meetings are held in weekends or late evening, statements are announced on the following dates. The number of such observations is 5 in our sample. 
our sample, the Fed has raised the FFTR 17 times, all by 25bp between 2004 and 2006. The decrease in FFTR has occurred 10 times and is concentrated in the 2007 - 2008 period with an average decrease of 51.25bp. We take these 27 observations as our policy events for our baseline event study. After that, the zero lower bound (ZLB) period follows, when the Fed could not lower the FFTR. During this period, the Fed has relied on so-called unconventional policies including quantitative easing, credit easing and signaling. Given that our focus is on the conventional monetary policy, we do not draw the event-study sample from this period.

\section{Measures of policy shock}

Following Kuttner (2001) and Cochrane and Piazzesi (2002), we identify the Fed's monetary policy shock based on the event-study type strategy. Essentially, this means that policy shock is gauged by adding up the innovations to a certain market interest rate over a short window around the policy relevant event, without imposing a specific model about the policy decision. It has been argued that this approach has several advantages over the alternative approaches. First, the market-based measures incorporate the massive amount of information about the Fed's policy through competition among asset market participants. A revision in the market interest rates would naturally reflect the corresponding surprise in information relevant to the Fed's policy outlook. Therefore, they are less prone to the omitted variable issues. Second, the model-free nature of the metrics means that they can accommodate the possibility that the policy maker's emphasis on various objectives may change over time as they are driven without imposing specific (parametric) models. For instance, it is possible that the Fed may react more aggressively to the GDP gap during the severe recession than the normal period. While not impossible, it is difficult for the standard regression based approaches to address this type of issues. Third, the identification using the high frequency data requires minimal assumptions. The high frequency identification implicitly assumes that the policy makers do not respond to the high frequency movement in the interest 
rates. While the policy makers can and will respond to information contained in interest rates before the FOMC meetings, it is much less likely that the Fed will react to the contemporaneous daily or weekly interest rate changes around the Fed's policy announcement. A similar identification assumption at the monthly frequency would be much more controversial; i.e. it is more difficult to argue that the Fed does not respond to contemporaneous interest rates in the monthly data. In general, the lower frequency identification requires more non-trivial assumptions. ${ }^{4)}$ We hope that our event-study identification strategy provides a robust picture concerning the causal relationship between the US monetary policy and international capital flow.

To choose the best policy shock measure that explains capital flows, we construct measures based on different financial instruments. We use the Federal fund futures, 1 month Eurodollar rates and 10 year Treasury yields. Gürkaynak, Sack and Swanson (2007) document that the Federal fund futures are the single best measure of the policy target over the short-term (1-5 months) and the Eurodollar rate reflects expectations over a slightly longer horizon. The response of the long-run Treasury yields is muted to policy shock when it is expected to be transient (Cochrane and Piazzesi, 2002).

When interest rates are used, the policy shock on date $d$ is estimated by:

$$
\Delta i_{d}^{u}=\sum_{j=k_{1}}^{k_{2}}\left(y_{d+j}-y_{d+j-1}\right)
$$

where $y_{d}$ represents the interest rate (Eurodollar rates or Treasury yields) on date $d$.

Due to the institutional background, the measure based the Federal fund futures requires a more delicate treatment. Since the Federal fund rate futures reflects the average Fed fund rates over the entire month, it needs to be scaled by the following equation to gauge daily policy shock:

$$
\Delta i_{d}^{u}=\sum_{j=k_{1}}^{k_{2}} \frac{D}{D-(d+j)}\left(f_{m, d+j}^{0}-f_{m, d+j-1}^{0}\right)
$$

4) For instance, the long-run neutrality of monetary policy can be challenged given the possibility of multiple equilibria and bifurcation. When the level of GDP gap can affect the GDP growth rate, the effect of monetary policy can be persistent even in the long run. 
Here $D$ is the number of dates in the month, $m$, and $f_{m, d}^{0}$ is the 'spot month' futures rate on date $d .5$ ) These Fed fund futures rates are obtained by 100 minus the contract price.

To obtain the weekly policy shock, we simply add the daily measure over the week following Cochrane and Piazzesi (2002).6) The expected component of the interest policy is given by the total change in the Fed's interest rate target, , minus policy shock or,

$$
\Delta i^{e}=\Delta i-\Delta i^{u}
$$

A more sophisticated identification scheme is to exploit high frequency heteroscedasticity in shock during the policy relevant dates. Rigobon and Sack (2004) show that this method relies on weaker assumptions and is more general than the event study style approaches outlined above. However, they also report that they do not find evidence that their methodology yields a different estimator than the alternatives. Therefore, we pursue the more simplistic event-study method.

\section{Empirical Results}

\section{Baseline event study}

This section presents the effects of the Fed's monetary policy on the international portfolio flows in S Korea by examining the individual flow during the weeks in which the Fed changed the policy interest rate. The average

5) To minimize the effect of the end-of-month noise in the effective fund rate, the unscaled changes in 1 month futures rate is used for the last three days of the month. Also, for the first date of month, or the one-month futures rate on the last day of the previous month is used instead of. See Kuttner (2001) for detail.

6) Cochrane and Piazzesi (2002) recommend use of and to correct for possible dating errors and information leak whereas Bernanke and Kuttner (2005) use. We follow the latter for our baseline analysis because (1) the Fed provides very detailed and accurate time line about the FOMC meetings for our sample period and (2) we aggregate the daily measure over week to get the weekly measure. This should guard against possible misdating and market reaction around the event date. 
Table 4: Average Statistics for Policy Measures (Unit: basis points)

\begin{tabular}{|c|c|c|c|c|}
\hline & $\begin{array}{c}(a) \\
\Delta i>0 \\
(n=17)\end{array}$ & $\begin{array}{c}(\mathrm{b}) \\
\Delta i<0 \\
(n=10)\end{array}$ & $\begin{array}{c}\text { (c) } \\
\text { FOMC, } \Delta i=0 \\
(n=69)\end{array}$ & $\begin{array}{c}(\mathrm{d}) \\
\text { Non-FOMC } \\
(n=507)\end{array}$ \\
\hline Total Fed rate change $(\Delta i)$ & 25.0 & -51.2 & 0.0 & 0.0 \\
\hline$\Delta i^{u, K}$ & 8.0 & -35.7 & -0.9 & 0.0 \\
\hline$\Delta i^{e, K}$ & 17.0 & -15.5 & - & - \\
\hline$\Delta i^{u, C P}$ & 1.0 & -27.7 & 3.6 & -0.1 \\
\hline$\Delta i^{e, C P}$ & 24.0 & -23.5 & - & - \\
\hline$\Delta i^{u, T B}$ & -0.1 & 0.7 & -3.0 & -0.0 \\
\hline$\Delta i^{e, T B}$ & 25.1 & -51.9 & - & - \\
\hline
\end{tabular}

Notes: $\Delta i^{u, X}$ and represent the unexpected and expected components of the Fed policy target change where $X=K$ denotes the measures are constructed using the Fed fund rate futures following Kuttner (2001) whereas $X=C P$ and $T B$ mean they use 1 month Eurodollar rate and 10-year Treasury yields, respectively. To get the policy shock corresponding to the weekly frequency, we add the daily measure over the week, following Cochrane and Piazzesi (2002). The expected component is the difference between the total rate change and the policy shock: $\Delta i^{e}=\Delta i-\Delta i^{u}$. The number in parentheses heading denotes the number of observations used for each column.

statistics concerning the policy shock measures are reported in Table 4. Column (a) shows that the expected component is much greater than the unexpected part during the latest boom cycle. In other words, a large part of the Fed's interest rate policy is anticipated in this period. On the other hand, the Fed's interest policy appears to have been relatively more aggressive than the market's expectation during the last recession in the sense that about a half of interest rate policy is shown unanticipated (column (b)). The measure based on the 10-year Treasury yield shows 'wrong' signs for both episodes.

This can be the reflection of the market expectation that the Fed's policy will reverse in the 10-year horizon, and thus is seen 'transient' in the long-run. Columns (c) and (d) find that the policy shock is much smaller for the weeks in which the FOMC meetings are held but the Fed has not changed the interest rate target and the non-FOMC weeks. Essentially, the changes in the FFTR appear to be the most important source of the monetary policy shock in our sample.

Table 5 reports the baseline event study results where the event period is defined as the week in which the Fed changes its target policy interest rate. Panel $\mathrm{A}$ is based on a regression of weekly equity flow, $F_{t}$, on the total (raw) 
Federal fund rate target:

$$
F_{t}=a+b \Delta i_{t}+\epsilon_{t}
$$

The dependent variable is standardized by division with its full sample standard deviation. The results show that, when the Fed increases its policy interest rate target, certain investor groups such as active, retail and Luxembourg increase their equity position during the policy event week and vice versa. No other equity investor groups have responded systematically to the Fed's interest rate policy. When the Fed increases its interest rate target by 25bps, on average, these groups of investors increase Korean equity worth 0.5-0.7x standard deviation during the event week.

The total effect of the policy change is decomposed into anticipated and unanticipated components using the following specification

$$
F_{t}=a+b^{u} \Delta i_{t}^{u}+b^{e} \Delta i_{t}^{e}+\epsilon_{t}
$$

Panel B reports the results based on model (3).7) The response to the unanticipated policy change appears to be more intense. For active, retail and Luxembourg funds (the same groups as above), a 25bp unanticipated policy rate hike leads to a contemporaneous net equity inflow of $0.7-1.0 \mathrm{x}$ standard deviation during the event week. The effect of anticipated shock is weaker.

Panels C and D report the results from similar exercises for the weekly bond flows. Overall, the effect of the US interest rate policy is mixed and possibly weaker for the bond flows during the policy event week. The raw effect of the US policy rate increase is negative for retail bonds. However, the Luxembourg bond funds have increased its position when the Fed increased FFTR. When the policy effect is decomposed, the effect of the policy surprise is negative for

\footnotetext{
7) In order to economize on the reporting space, we only report the results from the winner of the horse race exercises. It appears that the Fed fund rate futures is most relevant when it comes to explaining weekly capital flow. See Appendix A for details. Results based on other measures are available from the authors upon request.
} 


\section{Table 5: Baseline Estimation of the Fed's Policy Effect on Weekly Capital Flow}

For panels $A$ and $C$, we run a regression of weekly capital flows on a raw change in the FFTR expressed in percentage, where the capital flow is divided by its full sample standard deviation for standardization. Panels $B$ and $D$ are based on the regression of the standardized capital flow on the anticipated and unanticipated policy target change, all in percentage. Given the results of the horse-race exercises reported in Appendix A, we use the measure based on the Federal fund rate futures (Panels $B$ and $D$ ). Our sample for this exercise includes all weekly observations when the Fed changed the target policy rate. Therefore, except for the passive bond regression for which only 10 observations are available. The constant is suppressed in reporting. Numbers in parentheses are robust standard errors.,$+{ }^{*}$ and ${ }^{* *}$ denote statistical significance at the $10 \%, 5 \%$ and $1 \%$ levels, respectively.

Panel A: The effect of raw policy change on equity flow

\begin{tabular}{|c|c|c|c|c|c|c|c|c|}
\hline \multirow{3}{*}{$\Delta i$} & Aggregate & Active & Passive & Institution & Retail & US & Luxembourg & Ireland \\
\hline & 0.917 & $2.200^{*}$ & -0.383 & 0.031 & $2.706^{* *}$ & 0.498 & $1.947+$ & -0.202 \\
\hline & $(0.61)$ & $(0.82)$ & $(0.54)$ & (0.54) & $(0.90)$ & $(0.62)$ & (0.98) & $(0.91)$ \\
\hline$R^{2}$ & 0.094 & 0.259 & 0.025 & 0.000 & 0.241 & 0.028 & 0.137 & 0.001 \\
\hline \multicolumn{9}{|c|}{ Panel B: The effect of anticipated and unanticipated policy rate change on equity flow } \\
\hline & Aggregate & Active & Passive & Institution & Retail & US & Luxembourg & Ireland \\
\hline \multirow[t]{2}{*}{$\Delta i^{u}$} & 1.404 & $2.682+$ & -0.112 & -0.106 & $3.885^{* *}$ & 0.272 & $3.351^{* *}$ & 0.616 \\
\hline & $(1.05)$ & (1.33) & $(0.85)$ & $(0.94)$ & $(1.26)$ & (1.06) & $(1.19)$ & $(1.06)$ \\
\hline \multirow[t]{2}{*}{$\Delta i^{e}$} & 0.551 & $1.839^{*}$ & -0.587 & 0.134 & $1.820^{*}$ & 0.668 & 0.892 & -0.818 \\
\hline & $(0.42)$ & $(0.83)$ & $(0.53)$ & $(0.47)$ & $(0.72)$ & $(0.55)$ & $(0.82)$ & $(1.03)$ \\
\hline$R^{2}$ & 0.120 & 0.271 & 0.038 & 0.003 & 0.287 & 0.033 & 0.208 & 0.019 \\
\hline \multicolumn{9}{|c|}{ Panel C: The effect of raw policy change on bond flow } \\
\hline & Aggregate & Active & Passive & Institution & Retail & US & Luxembourg & Ireland \\
\hline \multirow[t]{2}{*}{$\Delta i$} & 0.354 & 0.191 & -1.146 & 0.192 & $-2.429^{* *}$ & -0.070 & $0.702^{*}$ & -0.028 \\
\hline & $(0.21)$ & (0.32) & (1.05) & $(0.23)$ & $(0.63)$ & $(0.28)$ & $(0.26)$ & $(0.23)$ \\
\hline$R^{2}$ & 0.142 & 0.021 & 0.185 & 0.047 & 0.242 & 0.007 & 0.288 & 0.001 \\
\hline $\begin{array}{c}\text { Panel D: The effect of anticipa } \\
\text { Aggregate Active }\end{array}$ & Aggregate & Active & Passive & Institution & Retail & US & Luxembourg & Ireland \\
\hline \multirow[t]{2}{*}{$\Delta i^{u}$} & 0.271 & -0.150 & -0.976 & 0.262 & $-2.573^{*}$ & $-0.460^{*}$ & $0.656^{*}$ & -0.149 \\
\hline & $(0.19)$ & $(0.29)$ & $(0.77)$ & $(0.21)$ & (0.93) & $(0.18)$ & $(0.29)$ & $(0.24)$ \\
\hline \multirow[t]{2}{*}{$\Delta i^{e}$} & 0.417 & 0.447 & -1.161 & 0.139 & $-2.320^{* *}$ & 0.223 & $0.736^{*}$ & 0.063 \\
\hline & $(0.31)$ & $(0.45)$ & (1.16) & $(0.34)$ & (0.69) & (0.38) & $(0.35)$ & $(0.28)$ \\
\hline$R^{2}$ & 0.149 & 0.086 & 0.196 & 0.054 & 0.243 & 0.208 & 0.289 & 0.016 \\
\hline
\end{tabular}

retail and US bond funds and positive for Luxembourg. This result is rather unsettling considering the conventional wisdom that the bond funds must be more sensitive to the interest rate changes than equity funds. The mixed and muted reaction of bond flows during the event week may suggest the possibility of pre-emptive portfolio rebalancing in anticipation of policy shifts. If this is true, the baseline results in Table 5 may be misleading, at least for the bond regressions. This idea is examined in Section $\mathbb{I I} .2$ below. 
In both Eqs (2) and (3), the error term represents factors which influence the contemporaneous weekly capital flow beyond the Fed's monetary policy. These are assumed unrelated to the Fed's interest rate policy. Often this assumption is justified in event study settings where the response of the dependent variable is examined over a short window. Moreover, the literature has shown that thethe effects of other macroeconomic news are minimal during the post-1994 when the FOMC meetings are arranged by exogenous schedules (Bernanke and Kuttner, 2005; Cieslak, Morse and Vissing-Jorgensen, 2014). In our sample all Fed's policy interest rate changes are made immediately after the scheduled meetings, softening concerns over contamination due to major macroeconomic news announcement around the policy change. The next section presents detailed discussion about this assumption. Then we show that the results are robust even if one source of endogeneity is directly controlled for.

\section{Robust tests}

The use of detailed high frequency data allows us to illuminate a richer and possibly different picture about the behaviors of international portfolio investors than studies based on lower frequency aggregate data. For instance, Lee and Kim (2014), based on monthly frequency data and SVAR identification, document that a positive US interest rate shock is associated with a short-run outflow in bond investment. Table 5 has shown that the response of foreign investors to the US monetary policy shock is not uniform in the high frequency data. Overall, this mixed response renders insignificant coefficients at the aggregate levels. A battery of regressions in this section shows that the aggregate and disaggregate equity flows do respond to the Fed's policy shock, positively. This result is robust to different choices of estimation methodologies and explicit control for the endogeneity. Moreover, once the effect of the pre-announcement adjustment is taken into account, the weekly bond flows also positively react to the US monetary policy shock. These are opposite to the findings in the literature. 


\section{2.a. Effect of influential observations}

Our first concern is that the baseline results may be driven by a few influential observations. This issue can be potentially serious considering the small sample size. Panels A and B of Table 6 report the results from the Huber (1973)'s robust regression, a.k.a. the M estimators. Observations with Cook's distance measure greater than 1 are defined outliers, and thus excluded. Then observations with large absolute values of residuals are underweighted using the iterative reweighted least square (IRLS) method. The baseline results in Table 5 are robust here. The only exception seems the regression of the passive equity flow, which shows a negative coefficient on the policy shock. However, its significance is only at the $10 \%$ level and it is one order of magnitude smaller than other significant coefficients. More importantly, the aggregate equity regression gains statistical significance here. When the $\mathrm{M}$ estimator is used, more of the bond flow regressions have significant coefficients on the policy shock. The sign is still mixed for the individual funds. The aggregate bond fund is still found unresponsive to the US monetary policy.

This method is known to be robust to large outliers in the response variables, but may fail when the outliers are in the regressors. To address this issue, we perform another set of diagnostic exercises using the Yohai (1987)'s MM estimator. This estimator is a mix of so-called the $\mathrm{S}$ and $\mathrm{M}$ estimators. The properties inherited from the $\mathrm{S}$ estimator grant resistance to outliers in regressors. It is also highly efficient thanks to its similarity with the $\mathrm{M}$ estimator. This is estimated by an iterative procedure described in Maronna et al. (2006).8) The results reported in Panels C and D of Table 6 show that the result from the Huber regression is unchanged for equity regressions. But many of the coefficients in bond regressions change the sign and gain statistical significance. This result suggests that the bond regressions may need further analysis.

8) One can also consider alternative estimators such as median/quantile regression or S estimator too. The low efficiency of these methods is highly unattractive to us considering the small sample size. 


\section{Table 6: Median and Robust Regressions of Capital Flow on Fedís Interest Rate Policy}

This table presents the robust check of the baseline estimation. For Panels A and B, we perform Huber (1973)' S iterated reweighted robust regressions after excluding observations with Cook' S D (1979) greater than 1. The constant is suppressed in reporting. Panels $C$ and D report the Yohai' $s$ MM estimator (1987) using the baseline regression model. For this estimation, we use the first-stage breakpoint of $50 \%$ and the efficiency of $85 \%$, following Maronna et al. (2006). Numbers in parentheses are robust standard errors.,$+{ }^{*}$ and ${ }^{* *}$ denote statistical significance at the $10 \%, 5 \%$ and $1 \%$ levels, respectively.

Panel A: Equity flow, Huber robust regression

\begin{tabular}{|c|c|c|c|c|c|c|c|c|}
\hline & Aggregate & Active & Passive & Institution & Retail & US & Luxembourg & Ireland \\
\hline \multirow[t]{2}{*}{$\Delta i^{u}$} & $1.018+$ & $2.350^{*}$ & $-0.683^{*}$ & 0.029 & $2.638^{* *}$ & 0.333 & $1.829^{* *}$ & $0.570^{*}$ \\
\hline & $(0.51)$ & $(1.01)$ & $(0.32)$ & $(0.51)$ & (0.66) & $(0.60)$ & (0.63) & $(0.22)$ \\
\hline \multirow{2}{*}{$\Delta i^{e}$} & 0.662 & $2.035+$ & $-1.087^{* *}$ & 0.370 & $1.383+$ & 0.900 & 0.292 & 0.314 \\
\hline & $(0.53)$ & $(1.05)$ & (0.33) & $(0.53)$ & $(0.69)$ & $(0.62)$ & $(0.65)$ & $(0.23)$ \\
\hline$N$ & 27 & 27 & 27 & 27 & 27 & 27 & 27 & 27 \\
\hline$R^{2}$ & 0.146 & 0.212 & 0.322 & 0.022 & 0.398 & 0.081 & 0.279 & 0.216 \\
\hline \multicolumn{9}{|c|}{ Panel B: Bond flow, Huber robust regression } \\
\hline & Aggregate & Active & Passive & Institution & Retail & US & Luxembourg & Ireland \\
\hline \multirow[t]{2}{*}{$\Delta i^{u}$} & 0.110 & -0.221 & $-1.591^{* *}$ & $0.401+$ & $-3.029^{* *}$ & $-0.775^{* *}$ & $0.783^{*}$ & $-0.234^{* *}$ \\
\hline & $(0.14)$ & $(0.21)$ & $(0.02)$ & $(0.20)$ & $(0.65)$ & $(0.07)$ & $(0.28)$ & $(0.03)$ \\
\hline \multirow[t]{2}{*}{$\Delta i^{e}$} & 0.082 & $-0.513^{* *}$ & $-2.077^{* *}$ & 0.093 & $-2.300^{* *}$ & $-0.645^{* *}$ & 0.272 & $-0.266^{* *}$ \\
\hline & $(0.12)$ & $(0.14)$ & $(0.02)$ & $(0.21)$ & $(0.68)$ & $(0.07)$ & $(0.19)$ & $(0.03)$ \\
\hline$N$ & 26 & 25 & 9 & 27 & 27 & 25 & 25 & 26 \\
\hline$R^{2}$ & 0.035 & 0.391 & 0.999 & 0.149 & 0.500 & 0.885 & 0.306 & 0.833 \\
\hline \multicolumn{9}{|c|}{ Panel C: Equity flow, Yohai robust regression } \\
\hline & Aggregate & Active & Passive & Institution & Retail & US & Luxembourg & Ireland \\
\hline \multirow[t]{2}{*}{$\Delta i^{u}$} & $0.868^{*}$ & -1.945 & -0.130 & -0.023 & $1.718^{* *}$ & 0.187 & $1.491^{*}$ & $0.534+$ \\
\hline & $(0.38)$ & $(2.89)$ & $(0.14)$ & $(0.39)$ & $(0.49)$ & $(0.47)$ & $(0.74)$ & $(0.29)$ \\
\hline \multirow[t]{2}{*}{$\Delta i^{e}$} & $0.690+$ & 1.495 & 0.241 & 0.440 & $1.207^{* *}$ & $0.942^{*}$ & 0.392 & 0.293 \\
\hline & $(0.41)$ & $(1.96)$ & $(0.18)$ & $(0.35)$ & $(0.43)$ & $(0.47)$ & $(0.46)$ & $(0.23)$ \\
\hline$N$ & 27 & 27 & 27 & 27 & 27 & 27 & 27 & 27 \\
\hline \multicolumn{9}{|c|}{ Panel D: Bond flow, Yohai robust regression } \\
\hline & Aggregate & Active & Passive & Institution & Retail & US & Luxembourg & Ireland \\
\hline \multirow[t]{2}{*}{$\Delta i^{u}$} & 0.101 & -0.514 & $0.274^{* *}$ & 0.488 & $-2.971^{* *}$ & $0.774^{* *}$ & 0.366 & $-0.225^{* *}$ \\
\hline & $(0.13)$ & $(0.43)$ & $(0.06)$ & $(0.41)$ & $(0.41)$ & $(0.04)$ & $(0.48)$ & $(0.07)$ \\
\hline \multirow[t]{2}{*}{$\Delta i^{e}$} & 0.107 & $-0.480^{*}$ & $0.280^{* *}$ & 0.277 & $-2.311^{* *}$ & $0.670^{* *}$ & 0.287 & $-0.265^{* *}$ \\
\hline & $(0.27)$ & $(0.21)$ & $(0.03)$ & $(0.20)$ & $(0.61)$ & $(0.05)$ & $(0.18)$ & $(0.04)$ \\
\hline$N$ & 27 & 27 & 10 & 27 & 27 & 27 & 27 & 27 \\
\hline
\end{tabular}

\section{2.b. Event study assumptions}

As discussed earlier, our baseline results rely on the assumption that the error term in model (2) and (3) are orthogonal to the Fed's monetary policy. In 
the face of seemingly puzzling findings concerning the behavior of the equity flow and to some extent the bond flows, some readers may suspect that our findings may be attributed to violation of this assumption. One classical type of such endogeneity would be that the Fed policy responds contemporaneously to the capital flow in South Korea. Clearly, this is highly implausible. Nonetheless, if the Fed is indeed worried about the contemporaneous capital inflow to South Korea from the world (i.e., capital outflow from the US), its policy action would work in the opposite direction of our equity flow regressions. Thus, it would result in a downward bias in the estimators and work against finding significant effects, at least for equity regressions.

A more subtle type of endogeneity can arise from a joint response of both the Fed's monetary policy and the capital flow to an unspecified third factor. For instance, it is possible that better-than-expected US GDP growth can induce the US monetary authority to raise the policy interest rate target. The same piece of information can induce world investors to rebalance their portfolios from international markets such as South Korea to the US in pursuit of a better prospect. Again, this type of indirect responses to common information reduces the estimated coefficients on the equity regressions.

Another concern arises because of potential mismatch between the policy shock and capital flow. In the typical event study framework, the response variables are examined over a predetermined narrow window around the event. While it is possible that we are able to identify the policy shock accurately at the daily frequency, the capital flow data are available at the weekly or monthly frequency. To operationalize our event study, we aggregate the daily policy shock over the week in which the Fed changed its interest rate target to get the weekly policy surprise measure. And we regress the contemporaneous weekly capital flow on the latter. Therefore, it is possible that our empirical strategy may attribute 'wrong' policy shocks to the capital flow. Moreover, the market participants may not have enough time to respond within the policy week if the policy announcement is made on the Friday afternoon. In our sample, however, this never happened. Of all 27 policy rate changes, 16 cases occurred on Tuesdays, 9 on Wednesdays and 2 on Thursdays. This ensures reasonable 
windows, e.g. days around the policy events. Of course, this weekly setting may not be satisfactory for die-hard event study purists. However, this situation can be modelled with errors-in-variable, in which the regressors are measured with errors where the measurement error is uncorrelated with factors affecting capital flow. Typically, it introduces so-called attenuation biases to estimators. Therefore, it would reduce the (absolute value of the) size of estimators and work against finding significant effects

\section{2.c. US business cycle and asymmetric responses}

The US business cycle may affect our estimates in two ways. First, the literature has shown that the US equity premium is counter-cyclical to the policy shock. For instance, Bernanke and Kuttner (2005) show that the return on the US equity index declines with the unanticipated contractionary Fed's policy. Essentially, it can be viewed that the equity return reacts to the business cycle information. It is possible that the decline in equity return reflects a capital outflow from the US to emerging markets. Similarly, as seen in Table 4, the Fed's interest rate policy and our policy shocks are positively associated. Given that the Fed's interest policy is counter-cyclical (i.e. the policy interest rate is increased during the boom cycle), it is possible that the positive coefficients on equity regressions are capturing fresh information contained in the Fed's interest rate policy about the US business cycle. Second, the estimators may be simply capturing the average difference in the capital flow over the cycle. Appendix B compares the detailed average capital flows over the US business cycle. To make the comparison consistent, we choose the weekly sample in which the Fed changed the policy interest rate target. While not uniform, both equity and bond capital flows tend to be higher during the boom cycle. This would work for explaining our baseline findings for the equity flow.

A related question concerning the US business cycle is the possibility of asymmetric reactions. Our baseline estimators capture the average effect of the US monetary policy across the boom and bust cycles. In the presence of asymmetries, it is possible that the average effect could be varying across the business cycle. 
Both of these issues can be addressed conveniently by including a dummy variable and its interaction with the policy shock. We set the dummy variable $D$ equal to 1 for the observations from the boom cycle and 0 otherwise.9) The results reported in Panel $\mathrm{A}$ in Table 7 are shocking. Most of the equity regressions have $R^{2}$ above $30 \%$. The regression of the active equity flow has the $R^{2}$ of $72 \%$ ! The effect of the US policy surprise on equity flow becomes highly significant and remains positive for all individual regressions except for the passive equity flow. The estimated effect of the policy shock increases by several folds compared to the baseline results. A negative coefficient on the interaction term implies that the magnitude of the policy surprise effect declines in the boom period. The interaction terms are significant only for aggregate, active and institutional equity funds, however. The significance is only at the $10 \%$ level too. Moreover, the total effect of the policy shock does not change its sign during the boom period.

Once the asymmetric responses are taken into account, the unconditional average equity flow is lower during the boom cycle (the estimator on $D$ is negative). This contrasts with the results in Appendix B which compares unconditional mean of capital flow across the US business cycle. Taken together, our baseline results for equity flows are confirmed and strengthened when the concerns over the US business cycle and asymmetries are explicitly modelled.

Once the asymmetric responses are taken into account, the unconditional average equity flow is lower during the boom cycle (the estimator on $\mathrm{D}$ is negative). This contrasts with the results in Appendix B which compares unconditional mean of capital flow across the US business cycle. Taken together, our baseline results for equity flows are confirmed and strengthened when the concerns over the US business cycle and asymmetries are explicitly modelled.

On the other hand, this specification is not as successful in explaining the bond flow as the equity flow. Panel B shows that the coefficient on the policy

9) Note that the dummy variable $D$ also captures the asymmetric response to the sign of the policy interest rate change because the direction of the policy interest rate and the business cycle is perfectly correlated. Therefore, one may argue that the causal effect identified by $D$ is blur. Since the one of the aims of the monetary policy is to stabilize the business cycle fluctuation, however, the main effect must be the latter. 


\section{Table 7: Test for Business Cycle Implications and Asymmetries}

This table presents the results from regression of standardized weekly portfolio flow in the South Korean market (capital flow/sample standard deviation) on the US policy shock and anticipated components, expressed in percentage. To examine the average effects and asymmetric response due to the US business cycle, we set 1 if the US economy is in a boom cycle (and thus, the Fed increased the policy target rate) and 0 , otherwise. The constant is suppressed in reporting. Numbers in parentheses are robust standard errors. $+{ }^{*}$ and ${ }^{* *}$ denote statistical significance at the $10 \%, 5 \%$ and $1 \%$ levels, respectively. The number of sample is 27 except for the passive bond where only 9 observations are available.

\begin{tabular}{|c|c|c|c|c|c|c|c|c|}
\hline & Aggregate & Active & Passive & Institution & Retail & US & Luxembourg & Ireland \\
\hline$\Delta i^{u}$ & $\begin{array}{c}7.370^{* *} \\
(1.79)\end{array}$ & $\begin{array}{c}10.667^{* *} \\
(1.46)\end{array}$ & $\begin{array}{l}3.747 \\
(2.32)\end{array}$ & $\begin{array}{c}5.665^{* *} \\
(1.61)\end{array}$ & $\begin{array}{c}9.529^{* *} \\
(2.32)\end{array}$ & $\begin{array}{c}6.334^{* *} \\
(1.93)\end{array}$ & $\begin{array}{c}8.571^{* *} \\
(2.23)\end{array}$ & $\begin{array}{l}5.481^{*} \\
(1.95)\end{array}$ \\
\hline$D=1$ & $-4.661^{* *}$ & $-6.116^{* *}$ & -3.050 & $-4.290^{* *}$ & $-4.546^{*}$ & $-4.554^{* *}$ & $-4.270^{*}$ & $-4.068^{*}$ \\
\hline if US boom & $(1.33)$ & $(1.04)$ & $(1.82)$ & $(1.31)$ & $(1.79)$ & $(1.58)$ & $(1.60)$ & $(1.76)$ \\
\hline \multirow[t]{2}{*}{$\Delta i^{u} \times D$} & $-2.615+$ & $-4.540+$ & -0.787 & $-2.508+$ & -3.103 & -2.339 & -3.254 & -1.298 \\
\hline & $(1.35)$ & $(2.26)$ & $(0.90)$ & $(1.22)$ & (2.39) & (1.54) & $(2.26)$ & $(1.86)$ \\
\hline \multirow[t]{2}{*}{$\Delta i^{e}$} & $5.723^{* *}$ & $8.732^{* *}$ & 2.683 & $4.827^{* *}$ & $6.899^{* *}$ & $5.690^{* *}$ & $5.706^{*}$ & $3.738^{*}$ \\
\hline & $(1.58)$ & $(1.24)$ & $(2.27)$ & $(1.39)$ & (2.04) & (1.64) & $(2.13)$ & (1.68) \\
\hline$R^{2}$ & 0.628 & 0.718 & 0.355 & 0.547 & 0.450 & 0.478 & 0.374 & 0.107 \\
\hline \multicolumn{9}{|c|}{ Panel B: Bond flow } \\
\hline & Aggregate & Active & Passive & Institution & Retail & US & Luxembourg & Ireland \\
\hline$\Delta i^{u}$ & $\begin{array}{l}0.677 \\
(0.49)\end{array}$ & $\begin{array}{l}0.825 \\
(0.86)\end{array}$ & $\begin{array}{c}-0.929 \\
(0.90)\end{array}$ & $\begin{array}{c}-0.019 \\
(0.64)\end{array}$ & $\begin{array}{c}-6.144 \\
(3.60)\end{array}$ & $\begin{array}{l}0.097 \\
(0.89)\end{array}$ & $\begin{array}{l}1.316^{*} \\
(0.58)\end{array}$ & $\begin{array}{l}0.166 \\
(0.79)\end{array}$ \\
\hline$D=1$ & -0.031 & -0.290 & 0.000 & 0.318 & 2.849 & -0.159 & -0.206 & 0.138 \\
\hline if US boom & (0.30) & $(0.48)$ & (.) & $(0.44)$ & (3.04) & $(0.56)$ & $(0.40)$ & $(0.47)$ \\
\hline \multirow[t]{2}{*}{$\Delta i^{u} \times D$} & -0.242 & -0.149 & 0.000 & 0.070 & -1.705 & 0.057 & -0.254 & -0.326 \\
\hline & $(0.51)$ & $(0.86)$ & (.) & $(0.44)$ & (2.19) & (0.53) & $(0.63)$ & $(0.55)$ \\
\hline \multirow[t]{2}{*}{$\Delta i^{e}$} & 0.110 & 0.220 & -1.207 & -0.378 & -4.966 & 0.125 & 0.564 & -0.530 \\
\hline & $(0.40)$ & $(0.72)$ & $(1.21)$ & $(0.75)$ & (3.12) & $(0.94)$ & $(0.47)$ & (0.63) \\
\hline$R^{2}$ & 0.340 & 0.140 & 0.235 & 0.196 & 0.347 & 0.013 & 0.471 & 0.288 \\
\hline
\end{tabular}

shock is insignificant in all regressions with the exception of the Luxembourg, showing that the EPFR weekly bond flows is unresponsive to the contemporaneous US policy surprise during the last decade. This finding is unsettling given the conventional wisdom that the bond funds are more sensitive to the interest rates than the equity funds.

Overall, this exercise provides further evidence that the event study methodology combined with the shock identified through high frequency market data finds a positive association between the US monetary policy shock and the weekly capital flows in S Korea. This is contrary to many recent studies. It is possible that our identification strategy captures different information than the alternatives. We discuss this issue in Section 3. 


\section{Full-sample regression analysis}

From the previous sections, we find that around the Fed's policy announcement week, a positive US interest rate shocks have a significant impact on equity fund inflow, but they have little impact on bond fund inflow in Korea. However, most of the previous studies report that the US interest rate shock and the capital flow in emerging markets are inversely associated. In other words, a (more-than-expected) contractionary US monetary policy is found to be related to a capital outflow from emerging capital markets. This is at odds with our findings of the event study. Following the methodologies of some of the previous studies (i.e., Koepke 2015), we extend our regression to the 'full' weekly sample (1w2004 and 29w2015). In this setting, we include push and pull factors from the literature as well as a lag of the dependent variable to minimize the omitted variable issues (Fratzscher, 2012; Koepke, 2015). Broadly speaking, these are variables that reflect risk and return of investing in international capital markets. The empirical model we investigate has a form as follows:

$$
F_{t}=a+b^{u} \Delta i_{t}^{u}+\rho F_{t-1}+X_{t}^{\prime} \beta+\epsilon_{t}
$$

where $X_{t}$ represent the vector of push and pull factors. See Appendix $\mathrm{C}$ for full list and short explanations. For the weeks when the Fed does not change its interest rate target, the anticipated component of policy, $\Delta i^{e}$, is simply $-\Delta i^{u}$, by (1). Since the meaning of anticipated component of policy is less clear in this context, it is not included in (4).

The full sample results are shown in Table 8 . The significant coefficients on the Fed policy shock are all negative. i.e. positive shock appears to be associated with capital outflow as in the literature. In unreported exercises, we have experimented with the variations of (4), by introducing the business cycle asymmetry as in Table 7 . Results are largely unchanged. For Table 8 , a weekly 
Table 8: Full Sample Regression

This table reports the regression of standardized capital flow on policy surprise, expressed in percentage. This full sample is dominated by non-event weeks when the Fed did not change the policy interest rate. Unlike the event study, 'push' and 'pull' factors are added as control variables. These are the variables known to affect international capital flow from the literature (See Koepke, 2015 and Appendix for details). To avoid potential problem of reverse feedback, we take a weekly lag of return variables such as interest rate spreads and equity returns. The number of observations used for these regressions is slightly smaller than the number of weeks during the sample period, due to missing data in some regressors. The constant is suppressed in reporting. Numbers in parentheses are standard errors robust to arbitrary structure of heteroscedasticity and autocorrelation.,$+{ }^{*}$ and ${ }^{* *}$ denote statistical significance at the $10 \%, 5 \%$ and $1 \%$ levels, respectively.

Panel A: Equity flow

\begin{tabular}{|c|c|c|c|c|c|c|c|c|}
\hline & Aggregate & Active & Passive & Institution & Retail & US & Luxembourg & Ireland \\
\hline$\Delta i^{u}$ & $\begin{array}{l}-0.243 \\
(0.30)\end{array}$ & $\begin{array}{c}-0.023 \\
(0.41)\end{array}$ & $\begin{array}{c}-0.721^{*} \\
(0.37)\end{array}$ & $\begin{array}{c}-0.813^{*} \\
(0.35)\end{array}$ & $\begin{array}{l}0.395 \\
(0.27)\end{array}$ & $\begin{array}{c}-0.916^{* *} \\
(0.27)\end{array}$ & $\begin{array}{l}0.457 \\
(0.36)\end{array}$ & $\begin{array}{c}-0.068 \\
(0.36)\end{array}$ \\
\hline $\begin{array}{l}\text { Lagged } \\
\text { Dependent }\end{array}$ & $\begin{array}{c}0.383^{* *} \\
(0.05)\end{array}$ & $\begin{array}{c}0.298^{* *} \\
(0.09)\end{array}$ & $\begin{array}{c}0.399^{* *} \\
(0.04)\end{array}$ & $\begin{array}{c}0.402^{* *} \\
(0.05)\end{array}$ & $\begin{array}{c}0.290^{* *} \\
(0.09)\end{array}$ & $\begin{array}{c}0.308^{* *} \\
(0.05)\end{array}$ & $\begin{array}{c}0.417^{* *} \\
(0.08)\end{array}$ & $\begin{array}{c}0.226^{* *} \\
(0.08)\end{array}$ \\
\hline Vix & $\begin{array}{c}-0.016+ \\
(0.01)\end{array}$ & $\begin{array}{c}-0.025^{*} \\
(0.01)\end{array}$ & $\begin{array}{c}-0.016+ \\
(0.01)\end{array}$ & $\begin{array}{c}-0.022^{*} \\
(0.01)\end{array}$ & $\begin{array}{c}-0.015 \\
(0.01)\end{array}$ & $\begin{array}{c}-0.020^{*} \\
(0.01)\end{array}$ & $\begin{array}{c}-0.016 \\
(0.01)\end{array}$ & $\begin{array}{c}-0.016 \\
(0.02)\end{array}$ \\
\hline $\begin{array}{l}\text { FOMC } \\
\text { dummy }\end{array}$ & $\begin{array}{l}0.035 \\
(0.09)\end{array}$ & $\begin{array}{c}-0.146+ \\
(0.08)\end{array}$ & $\begin{array}{c}-0.014 \\
(0.10)\end{array}$ & $\begin{array}{c}-0.070 \\
(0.10)\end{array}$ & $\begin{array}{c}-0.018 \\
(0.11)\end{array}$ & $\begin{array}{c}-0.075 \\
(0.10)\end{array}$ & $\begin{array}{l}0.010 \\
(0.11)\end{array}$ & $\begin{array}{c}-0.257+ \\
(0.15)\end{array}$ \\
\hline $\begin{array}{l}\text { US BBB } \\
\text { spread }\end{array}$ & $\begin{array}{l}0.000 \\
(0.00)\end{array}$ & $\begin{array}{l}0.000 \\
(0.00)\end{array}$ & $\begin{array}{l}0.000 \\
(0.00)\end{array}$ & $\begin{array}{l}0.001 \\
(0.00)\end{array}$ & $\begin{array}{c}-0.001 \\
(0.00)\end{array}$ & $\begin{array}{l}0.001 \\
(0.00)\end{array}$ & $\begin{array}{r}-0.001 \\
(0.00)\end{array}$ & $\begin{array}{l}0.001 \\
(0.00)\end{array}$ \\
\hline $\begin{array}{l}\text { Korea BBB } \\
\text { spread }\end{array}$ & $\begin{array}{l}0.083 \\
(0.11)\end{array}$ & $\begin{array}{l}0.054 \\
(0.15)\end{array}$ & $\begin{array}{l}0.179^{*} \\
(0.08)\end{array}$ & $\begin{array}{l}0.041 \\
(0.09)\end{array}$ & $\begin{array}{l}0.323 \\
(0.21)\end{array}$ & $\begin{array}{l}0.004 \\
(0.10)\end{array}$ & $\begin{array}{c}0.342+ \\
(0.19)\end{array}$ & $\begin{array}{l}0.093 \\
(0.16)\end{array}$ \\
\hline FX rate & $\begin{array}{l}0.230 \\
(0.86)\end{array}$ & $\begin{array}{l}1.076 \\
(1.19)\end{array}$ & $\begin{array}{c}-0.147 \\
(0.62)\end{array}$ & $\begin{array}{c}-0.023 \\
(0.70)\end{array}$ & $\begin{array}{l}1.265 \\
(0.98)\end{array}$ & $\begin{array}{l}0.634 \\
(0.81)\end{array}$ & $\begin{array}{l}0.263 \\
(0.89)\end{array}$ & $\begin{array}{c}-1.082 \\
(0.70)\end{array}$ \\
\hline $\begin{array}{l}\text { Korea and US } \\
\text { Treasury spread }\end{array}$ & $\begin{array}{l}0.020 \\
(0.05)\end{array}$ & $\begin{array}{l}0.011 \\
(0.06)\end{array}$ & $\begin{array}{l}0.025 \\
(0.03)\end{array}$ & $\begin{array}{l}0.059 \\
(0.04)\end{array}$ & $\begin{array}{c}-0.087 \\
(0.06)\end{array}$ & $\begin{array}{l}0.025 \\
(0.04)\end{array}$ & $\begin{array}{c}-0.009 \\
(0.05)\end{array}$ & $\begin{array}{l}0.050 \\
(0.05)\end{array}$ \\
\hline US equity return & $\begin{array}{l}0.068^{*} \\
(0.03)\end{array}$ & $\begin{array}{l}0.047 \\
(0.03)\end{array}$ & $\begin{array}{c}0.079^{* *} \\
(0.03)\end{array}$ & $\begin{array}{l}0.068^{*} \\
(0.03)\end{array}$ & $\begin{array}{l}0.056^{*} \\
(0.03)\end{array}$ & $\begin{array}{l}0.066^{*} \\
(0.03)\end{array}$ & $\begin{array}{l}0.092^{*} \\
(0.04)\end{array}$ & $\begin{array}{c}-0.003 \\
(0.02)\end{array}$ \\
\hline $\begin{array}{l}\text { Korea equity } \\
\text { return }\end{array}$ & $\begin{array}{l}0.001 \\
(0.02)\end{array}$ & $\begin{array}{l}0.015 \\
(0.04)\end{array}$ & $\begin{array}{c}-0.019 \\
(0.01)\end{array}$ & $\begin{array}{c}-0.019 \\
(0.02)\end{array}$ & $\begin{array}{l}0.019 \\
(0.04)\end{array}$ & $\begin{array}{c}-0.009 \\
(0.02)\end{array}$ & $\begin{array}{l}0.001 \\
(0.02)\end{array}$ & $\begin{array}{l}0.023 \\
(0.03)\end{array}$ \\
\hline $\begin{array}{l}\text { BRIC equity } \\
\text { return }\end{array}$ & $\begin{array}{l}0.047^{*} \\
(0.02)\end{array}$ & $\begin{array}{c}0.059^{* *} \\
(0.02)\end{array}$ & $\begin{array}{l}0.054^{*} \\
(0.03)\end{array}$ & $\begin{array}{l}0.060^{*} \\
(0.03)\end{array}$ & $\begin{array}{l}0.051^{*} \\
(0.02)\end{array}$ & $\begin{array}{l}0.061^{*} \\
(0.03)\end{array}$ & $\begin{array}{c}0.046^{* *} \\
(0.02)\end{array}$ & $\begin{array}{c}0.048^{* *} \\
(0.01)\end{array}$ \\
\hline$N$ & 582 & 582 & 582 & 582 & 582 & 582 & 582 & 582 \\
\hline$R^{2}$ & 0.276 & 0.271 & 0.290 & 0.310 & 0.282 & 0.238 & 0.382 & 0.119 \\
\hline
\end{tabular}




\section{Table 8: Full Sample Regression (continued)}

\begin{tabular}{lcccccccc} 
Panel B: Bond flow & \multicolumn{1}{c}{ Aggregate } & Active & Passive & Institution & Retail & US & Luxembourg & Ireland \\
$\Delta i^{u}$ & 0.046 & 0.028 & -0.057 & -0.004 & $-0.339^{*}$ & -0.132 & 0.071 & -0.033 \\
& $(0.15)$ & $(0.19)$ & $(0.16)$ & $(0.13)$ & $(0.16)$ & $(0.09)$ & $(0.21)$ & $(0.17)$ \\
Lagged & $0.510^{* *}$ & $0.659^{* *}$ & $0.123^{* *}$ & $0.332^{* *}$ & $0.678^{* *}$ & $0.453^{* *}$ & $0.585^{* *}$ & $0.411^{* *}$ \\
Dependent & $(0.12)$ & $(0.07)$ & $(0.04)$ & $(0.07)$ & $(0.05)$ & $(0.07)$ & $(0.09)$ & $(0.04)$ \\
Vix & -0.008 & -0.007 & -0.011 & $-0.016^{*}$ & -0.003 & $-0.017^{*}$ & -0.007 & -0.008 \\
& $(0.01)$ & $(0.01)$ & $(0.01)$ & $(0.01)$ & $(0.00)$ & $(0.01)$ & $(0.01)$ & $(0.01)$ \\
FOMC & 0.122 & 0.026 & $0.183^{*}$ & $0.234+$ & -0.006 & 0.018 & 0.000 & -0.027 \\
dummy & $(0.12)$ & $(0.13)$ & $(0.08)$ & $(0.12)$ & $(0.07)$ & $(0.07)$ & $(0.13)$ & $(0.11)$ \\
US BBB spread & -0.001 & -0.001 & -0.001 & -0.001 & $0.002^{* *}$ & -0.001 & -0.002 & -0.000 \\
& $(0.00)$ & $(0.00)$ & $(0.00)$ & $(0.00)$ & $(0.00)$ & $(0.00)$ & $(0.00)$ & $(0.00)$ \\
Korea BBB spread & 0.248 & 0.242 & 0.043 & 0.040 & -0.068 & 0.326 & $0.258+$ & 0.004 \\
& $(0.17)$ & $(0.15)$ & $(0.09)$ & $(0.15)$ & $(0.12)$ & $(0.25)$ & $(0.15)$ & $(0.13)$ \\
Fx rate & 0.269 & 0.012 & $0.883+$ & 0.076 & $-1.335^{* *}$ & -0.789 & 0.659 & 0.119 \\
& $(0.58)$ & $(0.46)$ & $(0.46)$ & $(0.74)$ & $(0.50)$ & $(0.83)$ & $(0.57)$ & $(0.68)$ \\
Korea and US & $0.105^{*}$ & $0.097^{*}$ & $0.149^{*}$ & $0.144^{* *}$ & 0.020 & $0.217^{* *}$ & 0.070 & $0.074^{*}$ \\
Treasury spread & $(0.05)$ & $(0.05)$ & $(0.06)$ & $(0.05)$ & $(0.03)$ & $(0.08)$ & $(0.04)$ & $(0.03)$ \\
US equity return & $0.063^{*}$ & $0.070^{*}$ & -0.019 & 0.030 & -0.016 & 0.021 & $0.088^{*}$ & 0.011 \\
& $(0.03)$ & $(0.03)$ & $(0.04)$ & $(0.02)$ & $(0.01)$ & $(0.02)$ & $(0.04)$ & $(0.03)$ \\
Korea equity return & -0.010 & $-0.023^{*}$ & 0.014 & -0.001 & $0.029^{*}$ & 0.008 & -0.022 & 0.009 \\
& $(0.01)$ & $(0.01)$ & $(0.03)$ & $(0.01)$ & $(0.01)$ & $(0.02)$ & $(0.02)$ & $(0.02)$ \\
BRIC equity return & $0.035^{*}$ & $0.032^{*}$ & 0.025 & $0.036+$ & -0.018 & $0.027^{*}$ & 0.028 & $0.046^{* *}$ \\
& $(0.01)$ & $(0.01)$ & $(0.02)$ & $(0.02)$ & $(0.01)$ & $(0.01)$ & $(0.02)$ & $(0.02)$ \\
$N$ & 582 & 582 & 423 & 582 & 582 & 582 & 582 & 582 \\
$R^{2}$ & 0.368 & 0.550 & 0.059 & 0.212 & 0.692 & 0.366 & 0.457 & 0.235 \\
\hline
\end{tabular}

lag is taken for return and interest rate variables to avoid the potential endogeneity issue. In other unreported exercises, we find the use of contemporaneous returns and interest rates does render them significant in many regressions. We find that it does not change the sign on the policy shock, however. We have included the expected policy change (for the event week only) in other exercises. It does not change the results much. These are available upon request. Taken together, the full sample regression produces results consistent with the findings in the literature. Furthermore, additional regression analyses are carried out by categorizing the international capital flow into fund type based on management style, types of investors, and country of fund source, respectively. We find that the effect of the US policy surprise has a significant negative impact on passive, institutional and US equity funds as well 
as retail bond funds. This indicates that those types of investor groups are likely to play an important role in changes of the international capital flow.

\section{Concluding Remarks}

This study has examined the spillover effects of US monetary policy on the international portfolio flows in South Korea by utilizing the novel high frequency dataset from the EPFR Global, tried-and-tested event study and the full sample regression analysis. We also use daily frequency asset returns for the identification of the policy surprise.

When only the policy event week is examined, we find that a positive surprise in the US interest rate policy is associated with a large equity capital inflow during the policy event week. We also find that some international equity investors respond to the expected component of the policy change. But its magnitude is smaller. Our results are robust to alternative estimation methods such as Huber and Yohai robust regressions. Further, we document evidence of asymmetric response of equity flows over the US business cycle. The response of the international equity investors in South Korea has been much more sensitive to the US policy shock during the recession than in the boom. This asymmetry model can explain a lion's share of the variation in the event-week equity flow with the $R^{2}$ as high as $72 \%$.

The picture from our event study is contrary to the literature, which documents a negative relationship between the Fed's monetary policy shock and the capital flows in emerging markets. We show that the difference in results may be attributed to a difference in identification, not in the use of the new high frequency data. Following previous literature, we run the full sample regression analysis after controlling for the push and pull factors that are likely to associated with the international capital flow. Consistent with previous studies, we find that unexpected US policy shocks have a significant negative impact on the international capital flow. In response to unexpected contractionary monetary policy shocks, the US, passive and institutional 
investors decrease their equity position while retail investors decrease their bond position. This result suggests that those types of investor groups are likely to play an important role in changes of the international capital flow. 


\section{References}

Bernanke, B. S. and K. N. Kuttner (2005), "What Explains the Stock Market's Reaction to Federal Reserve Policy?" The Journal of Finance, Vol. 60(3), pp. 1221-1257.

Cieslak, A., A. Morse, and A. Vissing-Jorgensen (2014), "Stock Returns Over the FOMC Cycle," NBER Working Paper.

Cochrane, J. H. and M. Piazzesi (2002), "The Fed and Interest Rates-a High-Frequency Identification," The American Economic Review, Vol. 92(2), pp. 90-95.

Cook, R. D. (1979), "Influential Observations in Linear Regression," Journal of the American Statistical Association, Vol. 74(365), pp. 169-174.

Craine, R, and V. L. Martin (2008), "International Monetary Policy Surprise Spillovers," Journal of International Economics, Vol. 75(1), pp. 180-196.

Fratzscher, M. (2012), "Capital Flow, Push Versus Pull Factors and the Global Financial Crisis," Journal of International Economics, Vol. 88(2), pp. 341-356.

Jotikasthira, C., C. Lundblad, and T. Ramadorai (2012), "Asset Fire Sales and Purchases and the International Transmission of Funding Shocks," The Journal of Finance, Vol. 67(6), pp. 2015-2050.

Gürkaynak, R. S., Brian P. S. and E. T. Swanson (2007), "Market-based Measures of Monetary Policy Expectations," Journal of Business \& Economic Statistics, Vol. 25(2), pp. 201-212.

Huber, P. J. (1973), "Robust regression: Asymptotics, conjectures and monte carlo." The Annals of Statistics, Vol. 1(5) 799-821.

Koepke, R. (2015), Fed Policy Expectations and Portfolio Flow to Emerging Markets, mimeo. 
Kuttner, K. N (2001), "Monetary Policy Surprises and Interest Rates: Evidence from the Fed Funds Futures Market," Journal of monetary economics, Vol. 47(3), pp. 523-544.

Lee, J. Y. and G. Y. Kim (2014), "International Portfolio Investment Behavior: Relationship between Bond and Equity Flow," Bank of Korea WP 14.

Maronna, R. A., R. D., Douglas Martin, and Victor Yohai (2006), Robust statistics, John Wiley \& Sons, Chichester, ISBN.

Rigobon, R., and B. Sack (2004), "The Impact of Monetary Policy on Asset Prices," Journal of Monetary Economics, Vol. 51(8), pp. 1553-1575.

Taylor, J. B (1993), "Discretion Versus Policy Rules in Practice," CarnegieRochester Conference Series on Public Policy, December, Vol. 39(0), pp. 195-214.

Yohai, V. J (1987), "High Breakdown-point and High Efficiency Robust Estimates for Regression," The Annals of Statistics, Vol. 15(2), pp. 642-656. 


\section{Appendix A. Horse Race of Policy Shock Measures}

This appendix reports the results of horserace among the different measures of policy shock. Overall, the measure based on the Fed fund rate futures is significant in more regressions than others. In OLS, we use the full sample, which includes all weeks when the Fed changed the policy target interest rate, i.e. $N=27$. To see the effect of influential observations, we run a Huber (1973) robust regression after removing observations with Cook' S D (1979) greater than 1. All numbers in parentheses are robust standard errors. ,$+{ }^{*}$ and ${ }^{* *}$ denote statistical significance at $10 \%, 5 \%$ and $1 \%$, respectively. We highlight $1 \%$ and $5 \%$ in yellow and $10 \%$ in green.

\section{Table A.1: Horse-Racing Among Policy Shock Measures}

Panel A: Equity flow, OLS ( $\mathrm{N}=27)$

\begin{tabular}{cccccccccc} 
& Aggregate & Active & Passive & Institution & Retail & US & Luxembourg & Ireland \\
$\Delta i^{u, K}$ & 0.934 & 1.331 & 0.240 & -0.301 & $2.712^{*}$ & -0.290 & $2.789^{*}$ & 0.944 \\
& $(0.91)$ & $(1.43)$ & $(0.78)$ & $(0.81)$ & $(1.29)$ & $(0.87)$ & $(1.03)$ & $(1.24)$ \\
$\Delta i^{u}, C P$ & 1.058 & 2.910 & -0.707 & 0.465 & 2.431 & 1.242 & 1.136 & -0.462 \\
& $(1.41)$ & $(1.73)$ & $(1.27)$ & $(1.39)$ & $(1.45)$ & $(1.42)$ & $(1.83)$ & $(1.70)$ \\
$\Delta i^{u}, T B$ & 0.527 & 2.402 & -0.856 & 0.828 & 2.041 & 1.438 & 1.798 & -4.309 \\
& $(1.16)$ & $(1.85)$ & $(0.99)$ & $(1.09)$ & $(2.74)$ & $(1.25)$ & $(2.89)$ & $(3.91)$ \\
$R^{2}$ & 0.127 & 0.289 & 0.036 & 0.023 & 0.275 & 0.070 & 0.216 & 0.083 \\
\hline
\end{tabular}

Panel B: Equity flow, robust regression

\begin{tabular}{ccccccccc} 
& Aggregate & Active & Passive & Institution & Retail & US & Luxembourg & Ireland \\
$\Delta i^{u, K}$ & 1.244 & $-4.984^{* *}$ & 0.063 & -0.147 & $3.331^{* *}$ & -0.015 & $2.699^{* *}$ & $1.999^{* *}$ \\
& $(0.84)$ & $(1.65)$ & $(0.31)$ & $(0.80)$ & $(1.00)$ & $(0.93)$ & $(0.90)$ & $(0.43)$ \\
$\Delta i^{u, C P}$ & 0.674 & $4.085^{*}$ & $-3.504^{* *}$ & 0.218 & 1.458 & 0.696 & 0.407 & -0.238 \\
& $(1.22)$ & $(1.74)$ & $(0.48)$ & $(1.16)$ & $(1.45)$ & $(1.35)$ & $(1.31)$ & $(0.62)$ \\
$\Delta i^{u, T B}$ & 0.956 & 2.601 & 0.316 & 1.078 & 0.596 & 1.995 & -0.621 & -0.171 \\
& $(1.35)$ & $(1.67)$ & $(0.48)$ & $(1.28)$ & $(1.61)$ & $(1.49)$ & $(1.45)$ & $(0.69)$ \\
$N$ & 27 & 26 & 26 & 27 & 27 & 27 & 27 & 27 \\
$R^{2}$ & 0.187 & 0.357 & 0.730 & 0.033 & 0.488 & 0.090 & 0.377 & 0.546 \\
\hline
\end{tabular}

Panel C: Bond flow, OLS ( $\mathrm{N}=27)$

\begin{tabular}{ccccccccc} 
& Aggregate & Active & Passive & Institution & Retail & US & Luxembourg & Ireland \\
$\Delta i^{u, K}$ & -0.188 & $-0.706^{*}$ & 0.090 & 0.033 & -1.261 & $-0.707^{* *}$ & -0.028 & -0.360 \\
& $(0.20)$ & $(0.32)$ & $(0.59)$ & $(0.21)$ & $(1.09)$ & $(0.21)$ & $(0.26)$ & $(0.26)$ \\
$\Delta i^{u, C P}$ & $1.118^{*}$ & 1.378 & 0.659 & 0.586 & $-2.688+$ & 0.589 & $1.616^{* *}$ & 0.583 \\
& $(0.53)$ & $(0.84)$ & $(1.28)$ & $(0.49)$ & $(1.37)$ & $(0.55)$ & $(0.56)$ & $(0.77)$ \\
$\Delta i^{u, T B}$ & $-1.009+$ & -1.260 & -0.623 & -0.510 & 1.853 & 0.014 & $-1.451^{*}$ & -1.066 \\
& $(0.58)$ & $(0.89)$ & $(1.02)$ & $(0.58)$ & $(2.43)$ & $(0.66)$ & $(0.64)$ & $(0.68)$ \\
$R^{2}$ & 0.401 & 0.304 & 0.101 & 0.153 & 0.169 & 0.247 & 0.494 & 0.227 \\
\hline
\end{tabular}


Panel D: Bond flow, robust regression

\begin{tabular}{ccccccccc} 
& Aggregate & Active & Passive & Institution & Retail & US & Luxembourg & Ireland \\
$\Delta i^{u, K}$ & -0.162 & $-0.508+$ & -0.171 & 0.224 & -1.607 & $-0.510^{* *}$ & 0.007 & -0.104 \\
& $(0.14)$ & $(0.25)$ & $(0.24)$ & $(0.30)$ & $(1.36)$ & $(0.11)$ & $(0.24)$ & $(0.06)$ \\
$\Delta i^{u, C P}$ & $0.587^{*}$ & 0.192 & -0.721 & -0.041 & -2.474 & $-0.393^{*}$ & $1.011^{* *}$ & -0.155 \\
& $(0.23)$ & $(0.45)$ & $(0.37)$ & $(0.49)$ & $(1.99)$ & $(0.19)$ & $(0.35)$ & $(0.10)$ \\
$\Delta i^{u, T B}$ & 0.045 & -0.346 & -0.770 & $-1.331^{*}$ & 0.694 & 0.188 & -0.354 & $0.213+$ \\
& $(0.24)$ & $(0.53)$ & $(0.60)$ & $(0.62)$ & $(2.20)$ & $(0.23)$ & $(0.39)$ & $(0.11)$ \\
$N$ & 26 & 25 & 9 & 26 & 27 & 26 & 27 & 26 \\
$R^{2}$ & 0.259 & 0.215 & 0.587 & 0.208 & 0.212 & 0.723 & 0.339 & 0.372 \\
\hline
\end{tabular}

\section{Appendix B. Comparison of Capital Flow Over US Business Cycle}

The sample is drawn from the weekly EPFR dataset, in which the Fed changed its target interest rate. For the bust cycle, the sample size is 10. The averages of the boom cycle capital flow are with 17 observations, except for passive bond flow which have no sample in the earlier period. The US business cycle is from the NBER.

Table B.1: Average capital flow over business cycle (Unit: \$, millions)

\begin{tabular}{lcccc} 
& \multicolumn{3}{c}{ Equity } & \multicolumn{2}{c}{ Bond } \\
\cline { 2 - 5 } Type & Bust & Boom & Bust & Boom \\
Aggregate & -24.0 & 31.5 & -7.1 & 2.2 \\
Active & -118.0 & 0.3 & -1.6 & 1.3 \\
Passive & 113.8 & 34.6 & 1.3 & n/a \\
Institutional & 60.4 & -11.0 & 0.14 & 2.5 \\
Retail & -61.0 & 75.6 & 18.0 & -7.5 \\
USA & 33.9 & 16.2 & 0.5 & 0.003 \\
Luxembourg & -40.2 & 42.3 & -8.1 & 2.1 \\
Ireland & -3.1 & -24.8 & -0.1 & -0.05 \\
\hline
\end{tabular}




\section{Appendix C. List of Push and Pull Factors Used in Full Sample Regression}

This appendix explains the push and pull factors used in full sample regression reported in Table 8. These are taken from Koepke (2015) and literature therein. Data on these variables are collected using Haver Analytics. To avoid the endogeneity issue, we use the one week lag of return variables in Table 8 .

\section{Variable}

Vix

US BBB Spread

Korea BBB Spread

FX rate

US Equity return S\&P500 index weekly return.

Korea equity return KOSPI weekly return.

BRIC equity return Simple average of broad based index in BRIC (Brazil, Russia, India and China).

Measure of implied volatility of S\&P 500 index option, available from CBOE. It gauges the market' $s$ expectation about the US market' $s$ volatility or perceived riskiness over the next 30 days.

This is spread between US Treasury bond and US BBB corporate bond index both with 3 year maturity. This captures the riskiness and return of investing in the US corporate bond market.

This is spread between Korean Treasury bond and Korean BBB corporate bond index both with 3 year maturity. This captures the riskiness and return of investing in Korean corporate bond market.

Foreign exchange rate between Korea and US (KRW/USD). A natural log is taken for the scale issue.

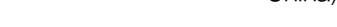




\section{$<$ Abstract in Korean $>$ \\ 미국의 통화정책이 자본유출입에 미치는 영향}

이지은*, 김정민**, 신종국***

본고에서는 미국의 정책금리 조정이 국내 주식시장 및 채권시장에 투자 하는 해외펀드의 자본유출입에 미치는 영향에 대해 EPFR GLOBAL의 주별 (weekly) 자본이동 자료를 이용하여 실증 분석하였다. 우선, 미국의 정책금리 인상(인하)이 나타났던 주를 중심으로 사건연구 방법을 수행한 결과, 주식시장의 경우 일시적으로 자본유입(유출)이 나타났으나, 채권시장의 경우 통계적으로 유의한 자본유출입 변동이 거의 나타나지 않았다. 영향력이 큰 관측치의 제거, 대안적 방법론 적용 및 내생성을 고려한 설명변수 추가 등 여러 강건성 (robustness) 검정에서도 본고의 분석결과는 동일하였다. 전체기간을 대상 으로 자본유출입에 영향을 주는 대내요인 및 대외요인을 통제한 후 미 연준 정책금리의 조정효과를 추정하였다. 분석결과, 미국의 예상치 못한 정책금리 인상(인하)은 해외펀드의 특성에 따라 차별적으로 유출(유입)될 가능성이 있음을 보였다. 특히, 미국의 예상치 못한 금리인상(인하) 시, 주식시장에서는 미국국적 투자자, 수동적 전략을 취하는 투자자, 기관투자자를 중심으로 자본유출(유입)이 나타났으며, 채권시장에서는 개인투자자를 중심으로 자본 유출(유입)이 나타났다.

핵심 주제어: 미국의 통화정책, 정책금리, 파급효과, 국제자본이동, 고빈도 식별, 사건연구

JEL Classification: E44, E52, E58, F32

\footnotetext{
* 한국은행 경제연구원 미시제도연구실 부연구위원 (전화: 02-759-5470, E-mail: jelee@bok.or.kr)

** 서울시립대학교 경영학부 조교수 (전화: 02-6490-2259, Email: kimjm2016@uos.ac.kr)

*** (교신저자) 뉴캐슬대학교 경제학과 교수 (E-mail: jong.shin@newcastle.ac.uk)
}

본 연구내용은 집필자의 개인의견이며 한국은행의 공식견해와는 무관합니다. 따라서 본 논문의 내용을 보도하거 나 인용할 경우에는 집필자명을 반드시 명시하여 주시기 바랍니다. 


\section{$\mathrm{BOK}$ 경제연구 발간목록}

한국은행 경제연구원에서는 Working Paper인 ${ }^{\mathrm{B} B O K}$ 경제연구』를 수시로 발간하고 있습니다. 『BOK 경제연구』는 주요 경제 현상 및 정책 효과에 대한 직관적 설명 뿐 아니라 깊이 있는 이론 또는 실증 분석을 제공함으로써 엄밀한 논증에 초점을 두는 학술논문 형태의 연구이며 한국은행 직원 및 한국은행 연구용역사업의 연구 결과물이 수록되고 있습니다.

${ }^{\circledR} \mathrm{BOK}$ 경제연구』는 한국은행 경제연구원 홈페이지(http://imer.bok.or.kr)에서 다운로드하여 보실 수 있습니다.

제2014-1 Network Indicators for Monitoring Intraday Liquidity in BOK-Wire+

2 중소기업에 대한 신용정책 효과

3 경제충격 효과의 산업간 공행성 분석

4 서비스업 발전을 통한 내외수 균형성장: 기대효과 및 리스크

5 Cross-country-heterogeneous and Time-varying Effects of Unconventional Monetary Policies in AEs on Portfolio Inflows to EMEs

6 인터넷뱅킹, 결제성예금 및 은행 수익성과의 관계 분석

7 Dissecting Foreign Bank Lending Behavior During the 2008-2009 Crisis

8 The Impact of Foreign Banks on Monetary Policy Transmission during the Global Financial Crisis of 2008-2009: Evidence from Korea

9 Welfare Cost of Business Cycles in Economies with Individual Consumption Risk

10 Investor Trading Behavior Around the Time of Geopolitical Risk Events: Evidence from South Korea

11 Imported-Inputs Channel of Exchange Rate Pass-Through: Evidence from Korean Firm-Level Pricing Survey
Seungjin Baek

Kimmo Soram ki . Jaeho Yoon

정호성·임호성

황선웅·민성환 ·

신동현 · 김기호

김승원 · 황광명

Kyoungsoo Yoon •

Christophe Hurlin

이동규·전봉걸

Moon Jung Choi •

Eva Gutierrez •

Maria Soledad Martinez Peria

Bang Nam Jeon •

Hosung Lim. Ji Wu

Martin Ellison •

Thomas J. Sargent

Young Han Kim •

Hosung Jung

Jae Bin Ahn -

Chang-Gui Park 


\begin{tabular}{|c|c|c|}
\hline 제2014-12 & 비대칭 금리기간구조에 대한 실증분석 & 김기호 \\
\hline 13 & $\begin{array}{l}\text { The Effects of Globalization } \\
\text { on Macroeconomic Dynamics } \\
\text { in a Trade-Dependent Economy: } \\
\text { the Case of Korea }\end{array}$ & Fabio Milani · Sung Ho Park \\
\hline 14 & $\begin{array}{l}\text { 국제 포트폴리오투자 행태 분석: 채권-주식 } \\
\text { 투자자금간 상호관계를 중심으로 }\end{array}$ & 이주용 · 김근영 \\
\hline 15 & $\begin{array}{l}\text { 북한 경제의 추격 성장 가능성과 } \\
\text { 정책 선택 시나리오 }\end{array}$ & 이근·최지영 \\
\hline 16 & $\begin{array}{l}\text { Mapping Korea's International Linkages } \\
\text { using Generalised Connectedness Measures }\end{array}$ & Hail Park $\cdot$ Yongcheol Shin \\
\hline 17 & $\begin{array}{l}\text { 국제자본이동 하에서 환율신축성과 } \\
\text { 경상수지 조정: 국가패널 분석 }\end{array}$ & 김근영 \\
\hline 18 & $\begin{array}{l}\text { 외국인 투자자가 외환시장과 주식시장 간 } \\
\text { 유동성 동행화에 미치는 영향 }\end{array}$ & 김준한 $\cdot$ 이지은 \\
\hline 19 & $\begin{array}{l}\text { Forecasting the Term Structure } \\
\text { of Government Bond Yields } \\
\text { Using Credit Spreads and Structural Breaks }\end{array}$ & $\begin{array}{l}\text { Azamat Abdymomunov } \\
\text { Kyu Ho Kang } \\
\text { Ki Jeong Kim }\end{array}$ \\
\hline 20 & $\begin{array}{l}\text { Impact of Demographic Change } \\
\text { upon the Sustainability of Fiscal Policy }\end{array}$ & $\begin{array}{l}\text { Younggak Kim· } \\
\text { Myoung Chul Kim } \\
\text { Seongyong Im }\end{array}$ \\
\hline 21 & $\begin{array}{l}\text { The Impact of Population Aging } \\
\text { on the Countercyclical Fiscal Stance in Korea, } \\
\text { with a Focus on the Automatic Stabilizer }\end{array}$ & $\begin{array}{l}\text { Tae-Jeong Kim } \cdot \\
\text { Mihye Lee } \cdot \text { Robert Dekle }\end{array}$ \\
\hline 22 & $\begin{array}{l}\text { 미 연준과 유럽중앙은행의 비전통적 통화정책 } \\
\text { 수행원칙에 관한 고찰 }\end{array}$ & 김병기·김진일 \\
\hline 23 & $\begin{array}{l}\text { 우리나라 일반인의 인플레이션 기대 형성 } \\
\text { 행태 분석 }\end{array}$ & 이한규·최진호 \\
\hline
\end{tabular}


제2014-24 Nonlinearity in Nexus between

Working Hours and Productivity

25 Strategies for Reforming Korea's Labor Market to Foster Growth

26 글로벌 금융위기 이후 성장잠재력 확충: 2014 한국은행 국제컨퍼런스 결과보고서

27 인구구조 변화가 경제성장률에 미치는 영향: 자본이동의 역할에 대한 논의를 중심으로

28 Safe Assets

29 확장된 실업지표를 이용한 우리나라 노동시장에서의 이력현상 분석

Entropy of Global Financial Linkages

31 International Currencies Past, Present and Future: Two Views from Economic History

32 금융체제 이행 및 통합 사례:

남북한 금융통합에 대한 시사점

Measuring Price-Level Uncertainty and Instability in the U.S., 1850-2012

고용보호제도가 노동시장 이원화

및 노동생산성에 미치는 영향

35 해외충격시 외화예금의 역할 : 주요 신흥국 신용스프레드에 미치는 영향을 중심으로 Emerging Market Economies, and Their Policy Responses
Dongyeol Lee

Hyunjoon Lim

Mai Dao · Davide Furceri •

Jisoo Hwang

Meeyeon Kim •

Tae-Jeong Kim

한국은행 경제연구원

손종칠

Robert J. Barro

김현학 · 황광명

Daeyup Lee

Barry Eichengreen

김병연

Timothy Cogley •

Thomas J. Sargent

김승원

정호성 - 우준명

김인수 · 이명수

황광명 - 김경민 -

노충식·김미진

Woon Gyu Choi •

Taesu Kang •

Geun-Young Kim •

Byongju Lee 
제2015-1 글로벌 금융위기 이후 주요국

통화정책 운영체계의 변화

2 미국 장기시장금리 변동이 우리나라 금리기간구조에 미치는 영향 분석 및 정책적 시사점

3 직간접 무역연계성을 통한 해외충격의 우리나라 수출입 파급효과 분석

4 통화정책 효과의 지역적 차이

5 수입중간재의 비용효과를 고려한 환율변동과 수출가격 간의 관계

6 중앙은행의 정책금리 발표가 주식시장 유동성에 미치는 영향

7 은행 건전성지표의 변동요인과 거시건전성 규제의 영향

8 Price Discovery and Foreign Participation in The Republic of Korea's Government Bond Futures and Cash Markets

9 규제가 노동생산성에 미치는 영향:

한국의 산업패널 자료를 이용한 실증분석

10 인구 고령화와 정년연장 연구

(세대 간 중첩모형(OLG)을 이용한 정량 분석)

11 예측조합 및 밀도함수에 의한 소비자물가 상승률 전망

12 인플레이션 동학과 통화정책

13 Failure Risk and the Cross-Section of Hedge Fund Returns

14 Global Liquidity and Commodity Prices

15 Foreign Ownership, Legal System and Stock Market Liquidity
김병기·김인수

강규호·오형석

최문정·김근영

김기호

김경민

이지은

강종구

Jaehun Choi - Hosung Lim •

Rogelio Jr. Mercado •

Cyn-Young Park

이동렬· 최종일·이종한

홍재화 - 강태수

김현학

우준명

Jung-Min Kim

Hyunju Kang •

Bok-Keun $\mathrm{Yu}$.

Jongmin $\mathrm{Yu}$

Jieun Lee $\cdot$ Kee H. Chung 
제2015-16 바젤 II 은행 경기대응완충자본 규제의 기준지표에 대한 연구

17 우리나라 대출 수요와 공급의 변동요인 분석

18 북한 인구구조의 변화 추이와 시사점

19 Entry of Non-financial Firms and Competition in the Retail Payments Market

20 Monetary Policy Regime Change and Regional Inflation Dynamics: Looking through the Lens of Sector-Level Data for Korea

21 Costs of Foreign Capital Flows in Emerging Market Economies: Unexpected Economic Growth and Increased Financial Market Volatility

22 글로벌 금리 정상화와 통화정책 과제: 2015년 한국은행 국제컨퍼런스 결과보고서

23 The Effects of Global Liquidity on Global Imbalances

24 실물경기를 고려한 내재 유동성 측정

25 Deflation and Monetary Policy

26 Macroeconomic Shocks and Dynamics of Labor Markets in Korea

27 Reference Rates and Monetary Policy Effectiveness in Korea

28 Energy Efficiency and Firm Growth

29 An Analysis of Trade Patterns in East Asia and the Effects of the Real Exchange Rate Movements

30 Forecasting Financial Stress Indices in Korea: A Factor Model Approach
서현덕·이정연

강종구 · 임호성

최지영

Jooyong Jun

Chi-Young Choi •

Joo Yong Lee

Roisin O'Sullivan

Kyoungsoo Yoon • Jayoung Kim

한국은행 경제연구원

Marie-Louise DJIGBENOU-KRE •

Hail Park

우준명·이지은

Barry Eichengreen

Tae Bong Kim •

Hangyu Lee

Heung Soon Jung •

Dong Jin Lee .

Tae Hyo Gwon .

Se Jin Yun

Bongseok Choi •

Wooyoung Park.

Bok-Keun Yu

Moon Jung Choi •

Geun-Young Kim • Joo Yong Lee

Hyeongwoo Kim • Hyun Hak Kim. Wen Shi 


\begin{tabular}{|c|c|c|}
\hline 제2016 -1 & $\begin{array}{l}\text { The Spillover Effects of U.S. Monetary } \\
\text { Policy on Emerging Market Economies: } \\
\text { Breaks, Asymmetries and } \\
\text { Fundamentals }\end{array}$ & $\begin{array}{l}\text { Geun-Young Kim } \\
\text { Hail Park } \\
\text { Peter Tillmann }\end{array}$ \\
\hline 2 & $\begin{array}{l}\text { Pass-Through of Imported Input Prices } \\
\text { to Domestic Producer Prices: Evidence } \\
\text { from Sector-Level Data }\end{array}$ & $\begin{array}{l}\text { JaeBin Ahn } \\
\text { Chang-Gui Park } \\
\text { Chanho Park }\end{array}$ \\
\hline 3 & $\begin{array}{l}\text { Spillovers from U.S. Unconventional } \\
\text { Monetary Policy and Its Normalization } \\
\text { to Emerging Markets: A Capital Flow } \\
\text { Perspective }\end{array}$ & $\begin{array}{l}\text { Sangwon Suh } \\
\text { Byung-Soo Koo }\end{array}$ \\
\hline 4 & $\begin{array}{l}\text { Stock Returns and Mutual Fund Flows } \\
\text { in the Korean Financial Market: } \\
\text { A System Approach }\end{array}$ & $\begin{array}{l}\text { Jaebeom Kim } \\
\text { Jung-Min Kim }\end{array}$ \\
\hline 5 & $\begin{array}{l}\text { 정책금리 변동이 성별·세대별 고용률에 } \\
\text { 미치는 영향 }\end{array}$ & 정성엽 \\
\hline 6 & $\begin{array}{l}\text { From Firm-level Imports to Aggregate } \\
\text { Productivity: Evidence from Korean } \\
\text { Manufacturing Firms Data }\end{array}$ & $\begin{array}{l}\text { JaeBin Ahn } \\
\text { Moon Jung Choi }\end{array}$ \\
\hline 7 & $\begin{array}{l}\text { 자유무역협정(FTA)이 한국 기업의 } \\
\text { 기업내 무역에 미친 효과 }\end{array}$ & 전봉걸·김은숙·이주용 \\
\hline 8 & $\begin{array}{l}\text { The Relation Between Monetary and } \\
\text { Macroprudential Policy }\end{array}$ & Jong Ku Kang \\
\hline 9 & $\begin{array}{l}\text { 조세피난처 투자자가 투자 기업 및 주식 } \\
\text { 시장에 미치는 영향 }\end{array}$ & 정호성·김순호 \\
\hline 10 & $\begin{array}{l}\text { 주택실거래 자료를 이용한 주택부문 거시 } \\
\text { 건전성 정책 효과 분석 }\end{array}$ & 정호성·이지은 \\
\hline 11 & $\begin{array}{l}\text { Does Intra-Regional Trade Matter in } \\
\text { Regional Stock Markets?: New } \\
\text { Evidence from Asia-Pacific Region }\end{array}$ & $\begin{array}{l}\text { Sei-Wan Kim } \\
\text { Moon Jung Choi }\end{array}$ \\
\hline 12 & $\begin{array}{l}\text { Liability, Information, and Anti-fraud } \\
\text { Investment in a Layered Retail } \\
\text { Payment Structure }\end{array}$ & $\begin{array}{l}\text { Kyoung-Soo Yoon } \\
\text { Jooyong Jun }\end{array}$ \\
\hline 13 & $\begin{array}{l}\text { Testing the Labor Market Dualism in } \\
\text { Korea }\end{array}$ & $\begin{array}{l}\text { Sungyup Chung } \\
\text { Sunyoung Jung }\end{array}$ \\
\hline 14 & $\begin{array}{l}\text { 북한 이중경제 사회계정행렬 추정을 통한 } \\
\text { 비공식부문 분석 }\end{array}$ & 최지영 \\
\hline
\end{tabular}




$\begin{array}{ll}\text { 제2016-15 } \begin{array}{ll}\text { Divergent EME Responses to Global } \\ \text { and Domestic Monetary Policy Shocks }\end{array} & \begin{array}{l}\text { Woon Gyu Choi } \\ \text { Byongju Lee } \\ \end{array} \\ & \text { Taesu Kang } \\ & \text { Geun-Young Kim }\end{array}$

16 Loan Rate Differences across Financial Byoung-Ki Kim • Sectors: A Mechanism Design Jun Gyu Min Approach

17 근로자의 고용형태가 임금 및 소득 분포 최충-정성엽 에 미치는 영향

18 Endogeneity of Inflation Target

Soyoung Kim • Geunhyung Yim

19 Who Are the First Users of a Newly-Emerging International Currency? A Demand-Side Study of Chinese Renminbi Internationalization

Hyoung-kyu Chey • Geun-Young Kim • Dong Hyun Lee

20 기업 취약성 지수 개발 및 기업 부실화에 대한 영향 분석

21 US Interest Rate Policy Spillover and International Capital Flow: Evidence from Korea

최영준

Jieun Lee • Jung-Min Kim • Jong Kook Shin 